\title{
Ceramide generation occurring during $7 \beta$-hydroxycholesterol- and 7-ketocholesterol-induced apoptosis is caspase independent and is not required to trigger cell death
}

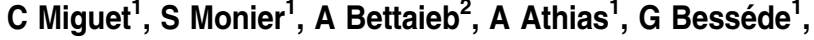 \\ A Laubriet ${ }^{3}$, S Lemaire ${ }^{1}$, D Néel ${ }^{1}$, P Gambert ${ }^{1}$ and G Lizard ${ }^{\star, 1}$ \\ ${ }^{1}$ CHU / Hôpital du Bocage, Laboratoire de Biochimie Médicale, Inserm U 498, BP \\ 1542, 21034 Dijon Cedex, France \\ 2 Faculté de Médecine et de Pharmacie, Inserm U 517, BP 87900, 21079 Dijon \\ Cedex, France \\ 3 Centre de Microscopie Préparative Appliquée á la Biologie et à la Médecine, \\ Faculté de Médecine, 7 Bd Jeanne d'Arc, 21033 Dijon, France \\ * Corresponding author: G Lizard, CHU / Hôpital du Bocage, Laboratoire de \\ Biochimie Médicale, Inserm U 498, BP 1542, 21034 Dijon Cedex, France \\ Tel: 333802938 53; Fax: 333802936 61; \\ E-mail: Gerard.Lizard@u-bourgogne.fr
}

Received 7.1.00; revised 24.8.00; accepted 25.9.00

Edited by RA Lockshin

\begin{abstract}
Biological activities of oxysterols seem tightly regulated. Therefore, the ability to induce cell death of structurally related oxysterols, such as those oxidized at $\mathrm{C} 7(7 \alpha-, 7 \beta$-hydroxycholesterol, and 7-ketocholesterol), was investigated on U937 cells at different times of treatment in a concentration range of $5-80 \mu \mathrm{g} / \mathrm{ml}$. Whereas all oxysterols accumulate inside the cells, strong inhibition of cell growth and increased permeability to propidium iodide were observed only with $7 \beta$-hydroxycholesterol and 7-ketocholesterol, which trigger an apoptotic process characterized by the occurrence of cells with fragmented and/or condensed nuclei, and by various cellular dysfunctions: loss of mitochondrial transmembrane potential, cytosolic release of cytochrome $c$, activation of caspase- 9 and -3 with subsequent enhanced activity of caspase-3, degradation of poly(ADP-ribose) polymerase, and increased accumulation of cellular C16:0 and C24:1 ceramide species. This ceramide generation is not attributed to caspase activation since inhibition of $7 \beta$-hydroxycholesterol- and 7-ketocholesterol-induced apoptosis by Z-VAD-fmk (100 $\mu \mathrm{M})$, a broad spectrum caspase inhibitor, did not reduce C16:0 and C24:1 ceramide species accumulation. Conversely, when U937 cells were treated with $7 \beta$-hydroxycholesterol and 7-ketocholesterol in the presence of fumonisin B1 (100 $\mu \mathrm{M})$, a specific inhibitor of ceramide synthase, C16: 0 and C24:1 ceramide species production was completely abrogated whereas apoptosis was not prevented. Noteworthy, $7 \alpha$ hydroxycholesterol induced only a slight inhibition of cell growth. Collectively, these results are consistent with the notion that the $\alpha$ or $\beta$ hydroxyl radical position of oxysterols
\end{abstract}

oxidized at $\mathrm{C} 7$ plays a key role in the induction of the apoptotic process. In addition, our findings demonstrate that $7 \beta$ hydroxycholesterol- and 7-ketocholesterol-induced apoptosis involve the mitochondrial signal transduction pathway and they suggest that C16:0 and C24:1 ceramide species generated through ceramide synthase play a minor role in the commitment of $7 \beta$-hydroxycholesterol- and 7-ketocholesterol-induced cell death. Cell Death and Differentiation (2001) 8 , 83-99.

Keywords: apoptosis; caspase-9; caspase-3; ceramide; cytochrome $c$; mitochondria; oxysterol; PARP

Abbreviations: $\mathrm{DiOC}_{6}(3), 3,3$ '-dihexyloxacarbocyanine iodide; PARP, poly(ADP-ribose) polymerase; PI, propidium iodide; ZVAD-fmk, N-benzyloxycarbonyl-valinyl-alaninyl-aspartyl fluoromethylketone; HMG-CoA reductase, 3-hydroxy-3-methylglutaryl coenzyme $A$ reductase

\section{Introduction}

Oxysterols are 27-carbon derivatives of cholesterol that contain additional oxygen atoms either on the steroid nucleus or on the side chain. ${ }^{1}$ These compounds constitute a wide family of molecules resulting either from the auto-oxidation of cholesterol in air, or from the enzyme-catalyzed transformation of cholesterol in various cell species. ${ }^{2,3}$ To date, oxysterols, which are present in various amounts in different kinds of foods, ${ }^{3-5}$ have been shown to possess diverse biological activities, ${ }^{6,7}$ and some of them are strongly cytotoxic to both normal and tumoral cells of human origin and from various animal species. ${ }^{8,9}$ However, from one oxysterol to another, important variations in the ability to induce cell death were observed. Thus, in cultured aortic smooth muscle cells the toxic potency differed with the oxysterol considered. ${ }^{10}$ In bovine aortic endothelial cells, we demonstrated that $7 \beta$-hydroxycholesterol and 7-ketocholesterol were more cytotoxic than 19-hydroxycholesterol, cholesterol $5 \alpha, 6 \alpha$-epoxide, and 25-hydroxycholesterol, and that their cytotoxicity was accompanied by an enhanced proportion of cells with fragmented and/or condensed nuclei characteristic of apoptotic cells. ${ }^{11}$ In human umbilical venous endothelial cells (HUVECs), ${ }^{12}$ in human, rabbit, and rat smooth muscle cells, ${ }^{12,13}$ as well as in leukemic cells such as $U 937$ promonocytic human leukemia cells, ${ }^{9,14,15}$ typical features of apoptosis were also observed under treatment with $7 \beta$-hydroxycholesterol and 7-ketocholesterol but not with 
$7 \alpha$-hydroxycholesterol. ${ }^{16}$ Taken together, these different observations underline the complexity of the biological activities of oxysterols, mainly of those oxidized at C7 (7 $\alpha$-, $7 \beta$-hydroxycholesterol and 7-ketocholesterol). Indeed, these oxysterols are detected in appreciable quantities in human tissues and fluids, including human plasma and atheromatous lesions, ${ }^{17}$ in oxidized low density lipoproteins (oxLDL) which play a key role at different stages of the atherosclerotic process, ${ }^{18,19}$ as well as in various kinds of food (powdered milk, cheese and egg products) especially when they are heated in air during processing and stored for a lengthy period. $^{20}$ Therefore, it is of importance to investigate the cytotoxicity of these oxysterols oxidized at $\mathrm{C} 7$, to precisely determine the mode of cell death that they induce, ${ }^{21,22}$ and to elucidate the signaling pathway(s) triggered by these compounds.

Since the biological activities of $7 \alpha-, 7 \beta$-hydroxycholesterol and 7-ketocholesterol seem tightly regulated, ${ }^{16,19}$ the cytotoxicities of these molecules were investigated in U937 cells in a range of concentrations varying from 5 to $80 \mu \mathrm{g} /$ $\mathrm{ml}(12.5-200 \mu \mathrm{M})$ after $30 \mathrm{~min}$ to $30 \mathrm{~h}$ of treatment by using different criteria: cell counting; flow cytometric measurement of cell permeability with propidium iodide ${ }^{11}$ observation by transmission electron microscopy; determination by fluorescence microscopy of the proportion of apoptotic cells displaying condensed and/or fragmented nuclei after DNA staining with Hoechst $33342 ;{ }^{23}$ quantification of cellular oxysterol concentration by gaseous phase chromatography coupled with mass spectrometry; ${ }^{24}$ flow cytometric quantification of mitochondrial transmembrane potential $\left(\Delta \psi_{\mathrm{m}}\right)$ with the cationic lipophilic dye $\mathrm{DiOC}_{6}(3)^{25}$ Western blot analysis of the release of cytochrome $c$ into the cytosol; activation of caspase-9 (MACH6/ICE-LAP6) and -3 (CPP32/apopain/Yama), and degradation of poly(ADP-ribose) polymerase (PARP). ${ }^{26}$ In addition, caspase-3 activity was simultaneously measured by a fluorogenic assay. According to these different criteria, $7 \alpha$ hydroxycholesterol was not cytotoxic and induced only a slight inhibition of cell growth, whereas it accumulates in the cells in higher amounts than $7 \beta$-hydroxycholesterol and 7-ketocholesterol. As for $7 \beta$-hydroxycholesterol and 7 ketocholesterol, they were potent inducers of cell death by apoptosis characterized by the following dysfunctions: inhibition of cell growth, increased permeability to propidium iodide, fragmentation and/or condensation of the nuclei, mitochondrial depolarization, cytochrome $c$ release into the cytosol, activation of caspase- 9 and -3 , and PARP degradation.

Since ceramides seem of fundamental importance in some signaling pathways leading to apoptosis, ${ }^{27-29}$ we further asked whether the different potencies of oxysterols to induce apoptosis could depend on their ability to stimulate ceramide generation. Thus, by electrospray ionization mass spectrometry, an important increase of cellular C16:0 and C24:1 ceramide accumulation was detected after treatment with $7 \beta$-hydroxycholesterol and 7 ketocholesterol, but not with $7 \alpha$-hydroxycholesterol. Interestingly, simultaneous incubation of $7 \beta$-hydroxycholesterol and 7-ketocholesterol with Z-VAD-fmk $(100 \mu \mathrm{M})$, a wide spectrum caspase inhibitor, ${ }^{30}$ impaired the apoptotic process but not ceramide generation, and otherwise simultaneous incubation of $7 \beta$-hydroxycholesterol and 7 ketocholesterol with fumonisin B1, a specific inhibitor of ceramide synthase, ${ }^{31}$ completely inhibited $\mathrm{C} 16: 0$ and C24:1 ceramide species generation without inhibiting apoptosis.

The reported data confirm that $7 \alpha$-hydroxycholesterol has no cytoxic effects, underlining that the pro-apoptotic effects of oxysterols oxidized at $\mathrm{C} 7$ depend not only on the radical (hydroxyl or keto) present at $\mathrm{C7}$, but also on the $\alpha$ or $\beta$ position of the hydroxyl radical, and they demonstrate that $7 \beta$-hydroxycholesterol- and 7-ketocholesterol-induced apoptosis characterized by a loss of mitochondrial transmembrane potential $\left(\Delta \psi_{\mathrm{m}}\right)$, a release of cytochrome $c$ into the cytosol, an activation of caspase- 9 and -3 , and a PARP degradation, is independent of the endogeneously generated C16:0 and C24:1 ceramide species.

\section{Results}

\section{Effects of $7 \alpha-, 7 \beta$-hydroxycholesterol and 7-ketocholesterol on cell growth and on cell permeability to propidium iodide}

Characterization of the effects of $7 \alpha-, 7 \beta$-hydroxycholesterol and 7-ketocholesterol $(5,10,20,40$ and $80 \mu \mathrm{g} / \mathrm{ml})$ on cell growth and on cell permeability to propidium iodide was performed on U937 cells at 18, 24 and $30 \mathrm{~h}$ of treatment. As shown in Figure 1, treatment of U937 cells with $7 \beta$ hydroxycholesterol and 7-ketocholesterol was associated with an inhibition of cell growth occuring in a dose-and timedependent manner. Thus, as early as $18 \mathrm{~h}$ after treatment has begun, $7 \beta$-hydroxycholesterol and 7-ketocholesterol significantly $(P<0.05)$ inhibited cell growth when they were used at minimum concentrations of 10 and $20 \mu \mathrm{g} / \mathrm{ml}$, respectively, and the most significant inhibition of cell proliferation for each compound was observed at $30 \mathrm{~h}$ of treatment (Figure 1). Interestingly, $7 \beta$-hydroxycholesterol was the strongest inhibitor of cell proliferation regardless of the time of treatment. When cells were treated with $7 \alpha$ hydroxycholesterol, a slight but significant inhibition of cell growth $(P<0.05)$ was observed only at $30 \mathrm{~h}$ of culture, when this oxysterol was used at the highest concentration investigated (80 $\mu \mathrm{g} / \mathrm{ml})$ (Figure 1). Because of the complex relationships between inhibition of cell growth and modification of cellular membrane integrity, flow cytometric analyses of cell permeability were performed with propidium iodide, which distinguishes between dead and living cells. ${ }^{32}$ In those conditions, strong increases in the proportions of propidium iodide positive cells were detected after $18 \mathrm{~h}$ of treatment with $7 \beta$-hydroxycholesterol and 7-ketocholesterol when these compounds were used at minimum concentrations of 20 and $40 \mu \mathrm{g} / \mathrm{ml}$, respectively, and the highest proportions of propidium iodide permeable cells were identified at $30 \mathrm{~h}$ of culture (Figure 1). Noteworthy, among the oxysterols oxidized at C7 ( $7 \alpha-, 7 \beta$-hydroxycholesterol and 7-ketocholesterol), $7 \beta$-hydroxycholesterol induced the highest proportion of cells permeable to propidium iodide regardless of the time of treatment, whereas no effect was 
Number of cells $\times 10^{6}$
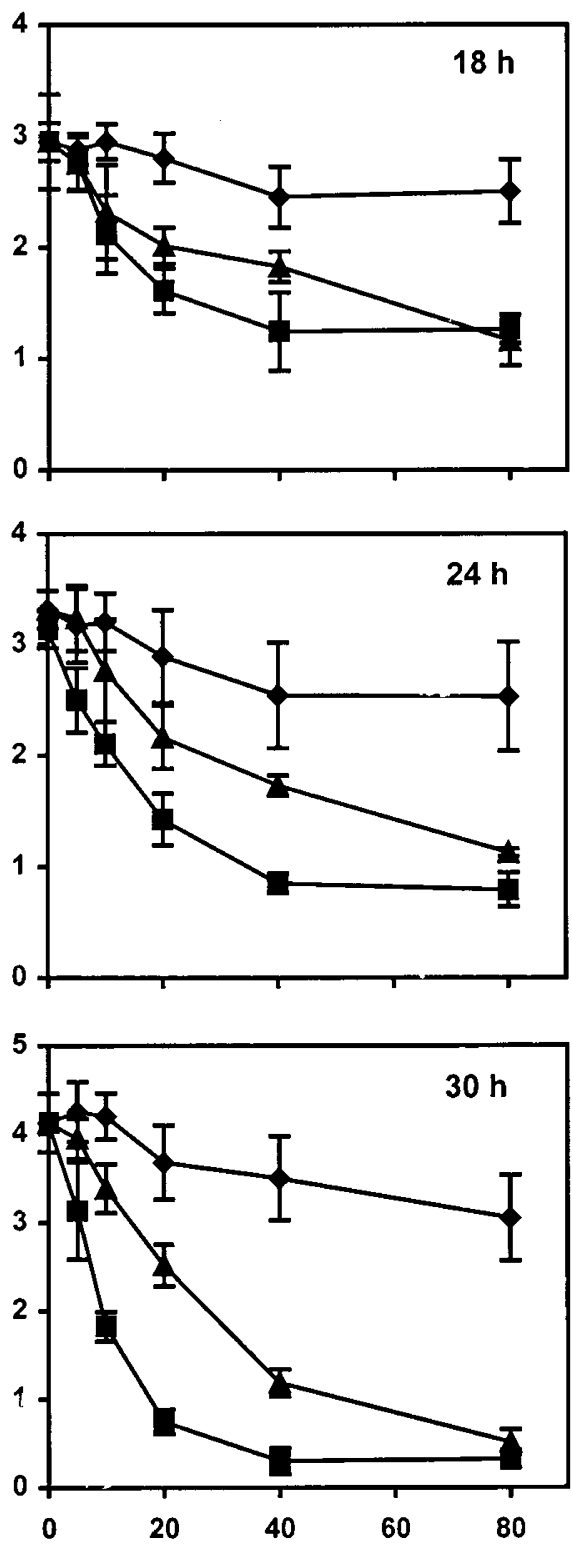

$\%$ of propidium iodide permeable cells
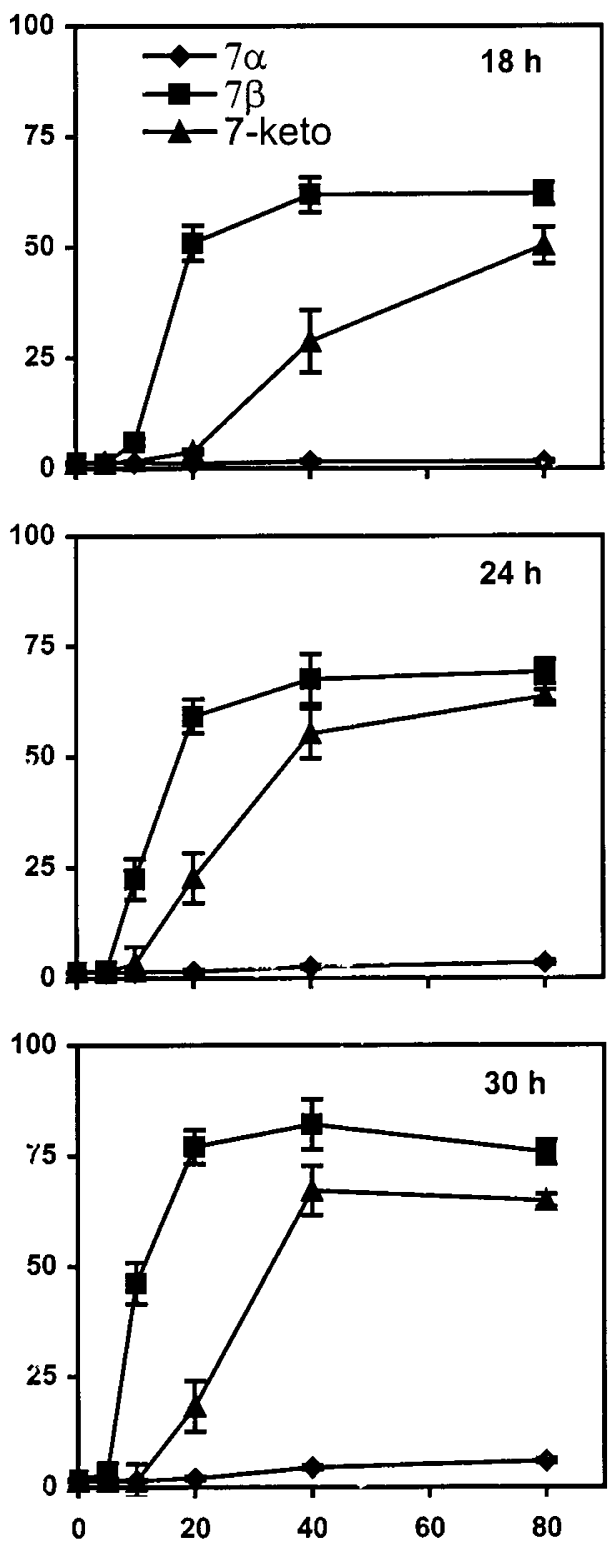

\section{Oxysterol concentrations $(\mu \mathrm{g} / \mathrm{ml})$}

Figure 1 Concentration and time-dependent effects of $7 \alpha, 7 \beta$-hydroxycholesterol and 7-ketocholesterol on cell growth and on cell permeability to propidium iodide. U937 cells were treated for 18,24 , and $30 \mathrm{~h}$ with either $7 \alpha$-hydroxycholesterol, $7 \beta$-hydroxycholesterol, or 7 -ketocholesterol in a range of concentrations from 5 to $80 \mu \mathrm{g} / \mathrm{ml}$. Cell growth was determined by cell counting, and the permeability to propidium iodide was quantified by flow cytometry. Data are mean \pm S.D. of four independent experiments performed in triplicate

observed with $7 \alpha$-hydroxycholesterol (Figure 1).

\section{Characterization of oxysterol-induced cell death}

When U937 cells were cultured in the presence of $7 \beta$ hydroxycholesterol or 7-ketocholesterol $(5,10,20,40$ and $80 \mu \mathrm{g} / \mathrm{ml}$ ) for 18,24 , and $30 \mathrm{~h}$, some cells with fragmented and/or condensed nuclei characteristic of apoptotic cells were identified by transmission electron microscopy, as well as by fluorescence microscopy after nuclei staining with Hoechst 33342 (Figures 2 and 3). The latter method, which was used to quantify apoptosis, showed a significant $(P<0.05)$ increase in apoptotic cells as early as $18 \mathrm{~h}$ of treatment when $7 \beta$ hydroxycholesterol and 7-ketocholesterol were used at minimum concentrations of 20 and $40 \mu \mathrm{g} / \mathrm{ml}$, respectively, and whatever the time of treatment the highest proportion of 

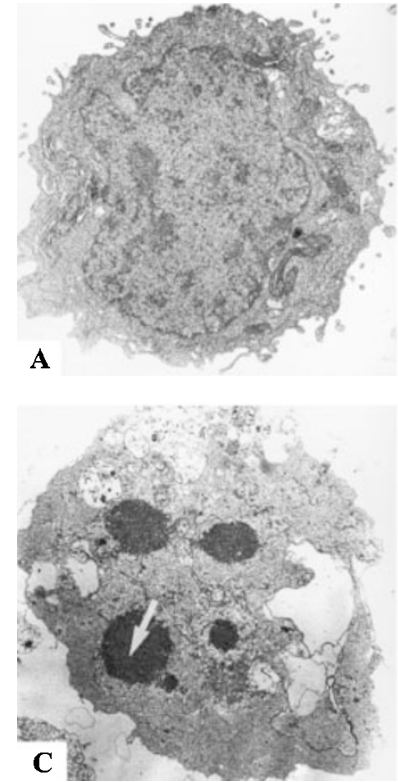
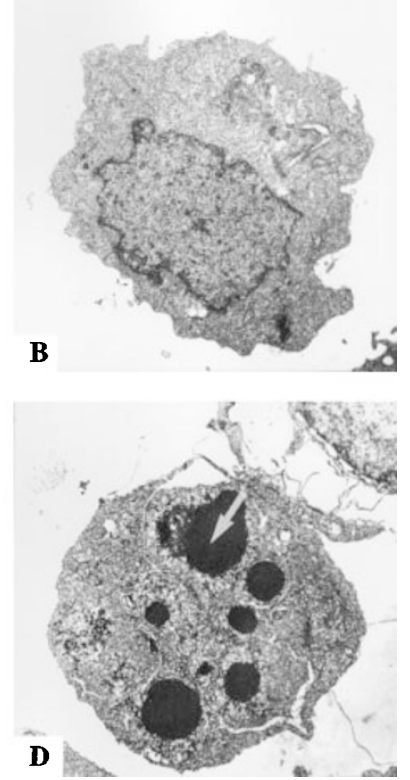

Figure 2 Morphological characterization of $7 \alpha-, 7 \beta$-hydroxycholesterol and 7-ketocholesterol-treated cells by transmission electron microscopy. U937 cells were cultured for $24 \mathrm{~h}$ in the absence (control) or in the presence of $7 \alpha$ hydroxycholesterol $(80 \mu \mathrm{g} / \mathrm{ml}), 7 \beta$-hydroxycholesterol $(20 \mu \mathrm{g} / \mathrm{ml})$, or 7 ketocholesterol $(40 \mu \mathrm{g} / \mathrm{ml})$, and the morphological aspects of the cells were analyzed by transmission electron microscopy (magnification $\times 3000)$ : $(\mathbf{A})$, control corresponding to untreated cells; (B), $7 \alpha$-hydroxycholesterol-treated cells. $7 \alpha$-hydroxycholesterol-treated cells are morphologically similar to untreated cells; (C), $7 \beta$-hydroxycholesterol-treated cells; (D), 7-ketocholesterol-treated cells. Apoptotic cells with fragmented nuclei (large arrows) obtained after treatment with $7 \beta$-hydroxycholesterol and 7-ketocholesterol are shown in C and D

apoptotic cells was obtained with $7 \beta$-hydroxycholesterol (Figure 4). When U937 cells were treated with $7 \alpha$-hydroxycholesterol, the morphological aspect of the cells and of their nuclei were the same as those of untreated cells when the observations were performed either by transmission electron microscopy or by fluorescence microscopy after nuclei staining with Hoechst 33342 (Figures 2 and 3). Thus, regardless of the time of treatment considered $(18,24$, and $30 \mathrm{~h}$ ), $7 \alpha$-hydroxycholesterol used at 5, 10, 20, 40, and $80 \mu \mathrm{g} /$ $\mathrm{ml}$ never induced apoptosis when this mode of cell death was characterized by the occurrence of cells with fragmented and/ or condensed nuclei (Figure 4).

For further characterization of cell death, $7 \beta$-hydroxycholesterol and 7-ketocholesterol were used at concentrations of 20 and $40 \mu \mathrm{g} / \mathrm{ml}$, respectively, since these were the lowest concentrations able to induce maximal proportions of apoptotic cells at 24 and $30 \mathrm{~h}$ of treatment (Figure 4). As $7 \alpha$-hydroxycholesterol was not an inducer of apoptosis, it was used at $80 \mu \mathrm{g} / \mathrm{ml}$ corresponding to the highest concentration investigated.

\section{Quantification of the intracellular uptake of $7 \alpha-$, $7 \beta$-hydroxycholesterol and 7-ketocholesterol}

In order to define whether the differences of toxicity between oxysterols oxidized at $\mathrm{C} 7$ were due to different uptakes from
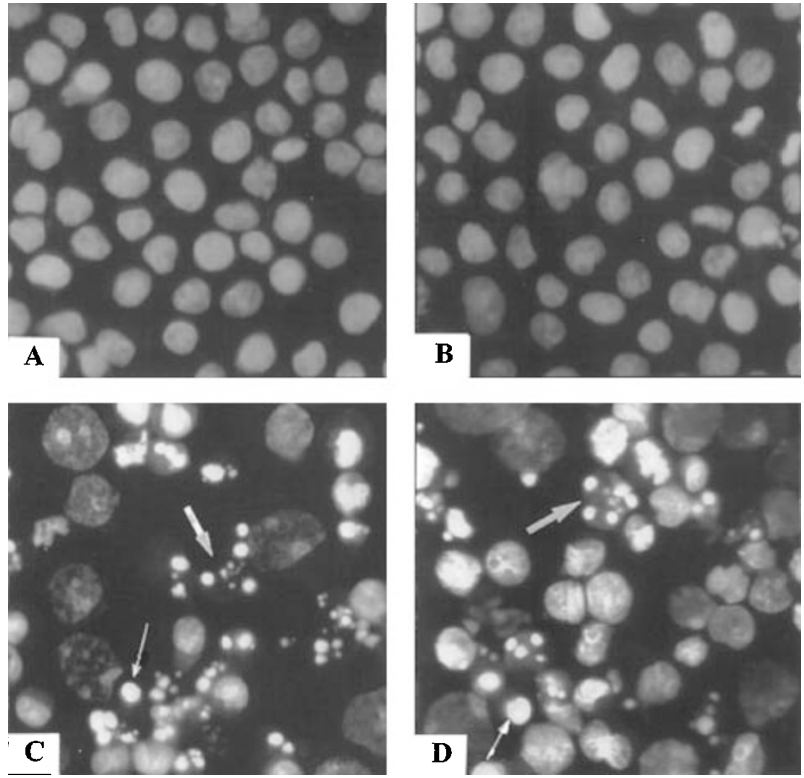

Figure 3 Morphological characterization of $7 \alpha-, 7 \beta$-hydroxycholesterol and 7 ketocholesterol-treated cells by fluorescence microscopy. U937 cells were cultured for $24 \mathrm{~h}$ in the absence (control) or in the presence of $7 \alpha$ hydroxycholesterol, $7 \beta$-hydroxycholesterol, or 7 -ketocholesterol in a range of concentrations from 5 to $80 \mu \mathrm{g} / \mathrm{ml}$, and the morphological aspects of the cells were analyzed by fluorescence microscopy after nuclei staining with Hoechst 33342 (magnification $\times 450$ ): $(\mathbf{A})$, control corresponding to untreated cells; (B), $7 \alpha$-hydroxycholesterol-treated cells $(80 \mu \mathrm{g} / \mathrm{ml}) ;($ C), $7 \beta$-hydroxycholesterol-treated cells (20 $\mu \mathrm{g} / \mathrm{ml})$; (D), 7-ketocholesterol-treated cells $(40 \mu \mathrm{g} / \mathrm{ml})$. Apoptotic cells with fragmented (large arrows) and/or condensed nuclei (small arrows) were observed after treatment with $7 \beta$-hydroxycholesterol and 7 ketocholesterol but not among $7 \alpha$-hydroxycholesterol-treated cells, which were morphologically similar to untreated cells

one oxysterol to another, the quantity of oxysterol (per cell) was quantified at $24 \mathrm{~h}$ of treatment by capillary gas chomatography coupled to mass spectrometry. In these conditions, when the cells were treated for $24 \mathrm{~h}$ in the presence of oxysterols used at final concentrations of 5,10 , 20,40 and $80 \mu \mathrm{g} / \mathrm{ml}$, the uptake of $7 \alpha$-hydroxycholesterol was approximately twofold higher than those obtained with $7 \beta$ hydroxycholesterol and 7-ketocholesterol. Thus, when cells were treated with $7 \alpha$-hydroxycholesterol at concentrations of 5 to $80 \mu \mathrm{g} / \mathrm{ml}$, the uptake of this oxysterol varied from $8.22 \pm 1.8$ to $104.95 \pm 14.21 \mu \mathrm{g} / 10^{6}$ cells (Table 1 ). When cells were treated with $7 \beta$-hydroxycholesterol and 7-ketocholesterol at final concentrations of 5 to $80 \mu \mathrm{g} / \mathrm{ml}$, the uptakes of these oxysterols were similar and varied from $3.40 \pm 1.30$ to $65.00 \pm 5.50 \mu \mathrm{g} / 10^{6}$ cells, and from $4.30 \pm 1.38$ to $53.08 \pm 7.94 \mu \mathrm{g} / 10^{6}$ cells, respectively (Table 1 ).

\section{Effect of $7 \alpha-, 7 \beta$-hydroxycholesterol and 7-ketocholesterol on mitochondrial transmembrane potential $\left(\Delta \psi_{\mathrm{m}}\right)$ and on cytochrome $c$ release into the cytosol}

Disruption of $\Delta \psi_{\mathrm{m}}$ and cytochrome $c$ release from the intermembrane space of mitochondria into the cytosol seems a general feature of apoptosis. ${ }^{33}$ Therefore, in the presence of $7 \beta$-hydroxycholesterol $(20 \mu \mathrm{g} / \mathrm{ml})$ and 7-ketocholesterol 

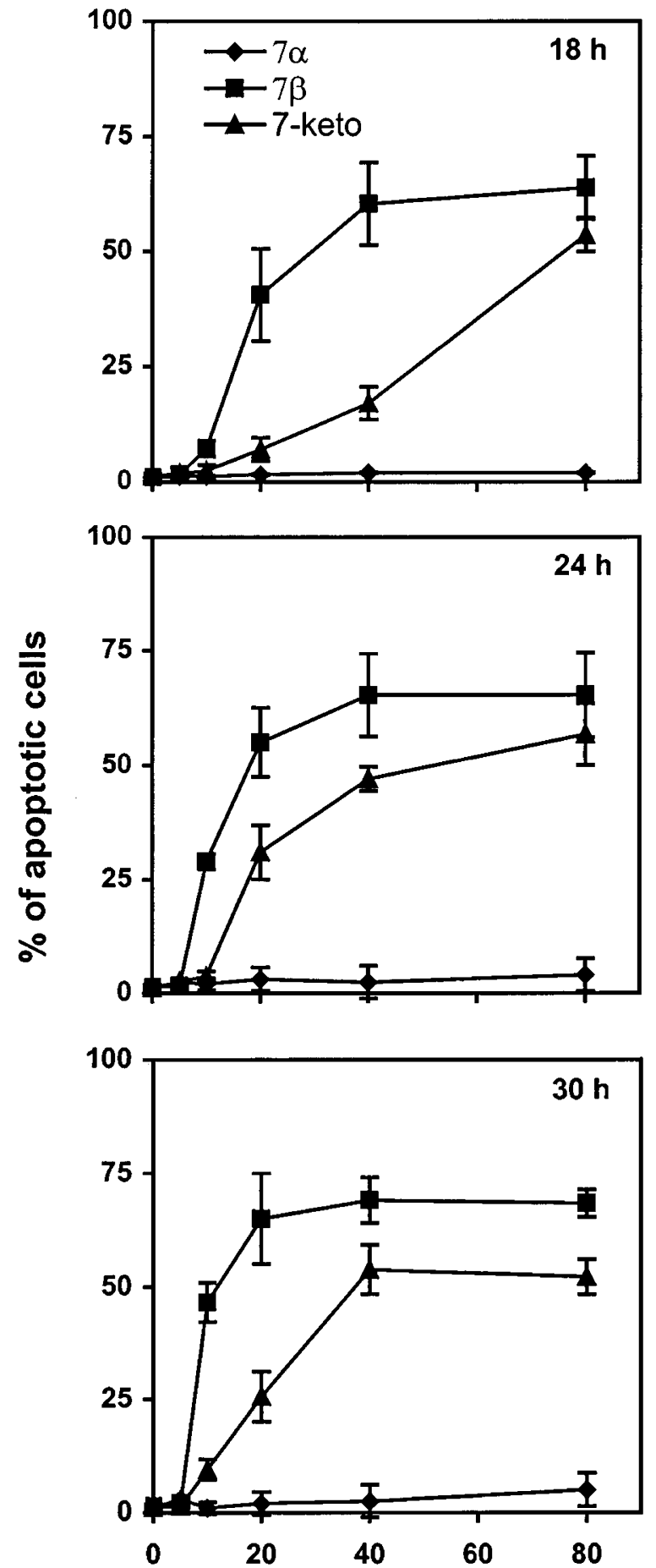

\section{Oxysterol concentrations $(\mu \mathrm{g} / \mathrm{ml})$}

Figure 4 Concentration and time-dependent effect of $7 \alpha-, 7 \beta$-hydroxycholesterol and 7-ketocholesterol on the induction of apoptotic cells. To quantify the percentage of apoptotic cells, U937 cells were treated for 18,24 , and $30 \mathrm{~h}$ with either $7 \alpha$-hydroxycholesterol $(80 \mu \mathrm{g} / \mathrm{ml}), 7 \beta$-hydroxycholesterol $(20 \mu \mathrm{g} / \mathrm{ml})$, or 7-ketocholesterol $(40 \mu \mathrm{g} / \mathrm{ml})$. Apoptotic cells characterized by condensed and/ or fragmented nuclei were identified by fluorescence microscopy after DNA staining with Hoechst 33342 . Data are mean \pm S.D. of four independent experiments performed in triplicate
( $40 \mu \mathrm{g} / \mathrm{ml})$, the evolution of $\Delta \psi_{\mathrm{m}}$ and the processing of cytochrome $c$ release were simultaneously quantified after various treatment times $(18,24$, and $30 \mathrm{~h}$ ) by flow cytometry with the cationic lipophilic dye $\mathrm{DiOC}_{6}(3)$, and by Western blot with a mouse monoclonal antibody directed against cytochrome $c$ (molecular weight $15 \mathrm{kD}$ ), respectively. The levels of cytochrome $c$ release into the cytosol were quantified comparatively to the constant level of a cross reacting protein of around $65 \mathrm{kD}$ present in the cytosolic extract. When compared to untreated cells, treatment with $7 \beta$-hydroxycholesterol and 7-ketocholesterol resulted in a time-dependent increase of the percentage of depolarized cells (characterized by low values of $\Delta \psi_{\mathrm{m}}$ ) which were observed as early as $18 \mathrm{~h}$ after treatment, and the effects were more marked with $7 \beta$ hydroxycholesterol than with 7-ketocholesterol (Table 2). This increase in the percentage of cells with low $\Delta \psi_{\mathrm{m}}$ was associated with a cytosolic release of cytochrome $c$ which was already significant at $18 \mathrm{~h}$ of treatment; with 7ketocholesterol, the cytosolic release of cytochrome $c$ was slightly detected at $18 \mathrm{~h}$, but was more and more pronounced at 24 and $30 \mathrm{~h}$ of treatment (Table 2). $7 \alpha$-hydroxycholesterol induced only a slight but not significant increase in the proportion of depolarized cells, and when treated with this oxysterol no cytosolic release of cytochrome $c$ was observed (Table 2).

\section{Analysis of caspase- 9 and -3 activation, and of poly(ADP-ribose) polymerase degradation in $7 \alpha$-, $7 \beta$-hydroxycholesterol- and 7-ketocholesterol- treated U937 cells}

As the loss of mitochondrial transmembrane potential $\left(\Delta \psi_{\mathrm{m}}\right)$ and the release of cytochrome $c$ generally leads to subsequent activation of caspase- 9 , and -3 , as well as to PARP degradation, ${ }^{34-36}$ the occurrence of this cascade of events was investigated during $7 \beta$-hydroxycholesterol and 7-ketocholesterol-induced apoptosis. To this end, U937 cells were treated for 18,24 , and $30 \mathrm{~h}$ with $7 \beta$-hydroxycholesterol $(20 \mu \mathrm{g} /$ $\mathrm{ml})$, or 7-ketocholesterol ( $40 \mu \mathrm{g} / \mathrm{ml})$, and Western blot analysis was used to demonstrate the involvement of caspase- 9 and -3 , as well as PARP degradation. In addition, caspase- 3 activity was simultaneously measured by a fluorogenic assay based on the cleavage of Ac-DEVD-7-amino-4-methylcoumarin. When compared to untreated cells, incubation with $7 \beta$ hydroxycholesterol resulted in the degradation of procaspase- 9 as well as in the cleavage of procaspase-3 (32 kD) in its active subunit (17 kD) as early as $18 \mathrm{~h}$ after treatment (Table $3)$. In the presence of 7-ketocholesterol, degradation of procaspase- 9 and cleavage of procaspase-3 were not observed at $18 \mathrm{~h}$ but they began to be detected at $24 \mathrm{~h}$, and were more pronounced at $30 \mathrm{~h}$ (Table 3 ). This cleavage of procaspase- 3 occurring when treated with $7 \beta$-hydroxycholesterol and with 7-ketocholesterol was associated with an increase of caspase- 3 activity (Table 3 ). In untreated cells and in the presence of $7 \alpha$-hydroxycholesterol $(80 \mu \mathrm{g} / \mathrm{ml})$, no degradation of procaspase- 9 , no cleavage of procaspase-3, and no caspase-3 activity were ever observed (Table 3 ).

The findings that oxysterols induce the activation of caspase-3 prompted an analysis of poly(ADP-ribose) polymerase (PARP) cleavage since one of the potential 
Table 1 Uptake of $7 \alpha-, 7 \beta$-hydroxycholesterol and 7-ketocholesterol in U937 cells after $24 \mathrm{~h}$ of treatment

\begin{tabular}{|c|c|c|c|}
\hline $\begin{array}{l}\text { Treatment with } 7 \alpha \text {-, } \\
7 \beta \text {-hydroxycholesterol }\end{array}$ & $7 \alpha-$ & $\begin{array}{l}\text { holesterol or } 7-\text { ketocho } \\
\qquad\left(\mu \mathrm{g} / 10^{6} \text { cells }\right)\end{array}$ & \\
\hline $\begin{array}{l}\text { or 7-ketocholesterol } \\
(\mu \mathbf{g} / \mathrm{ml})\end{array}$ & $7 \alpha$-hydroxycholesterol & 7 $\beta$-hydroxycholesterol & 7-ketocholesterol \\
\hline $\begin{array}{r}0 \\
5 \\
10 \\
20 \\
40 \\
80\end{array}$ & $\begin{array}{c}0 \\
8.22 \pm 1.80 \\
15.73 \pm 5.32 \\
35.90 \pm 1.27 \\
52.60 \pm 6.50 \\
104.95 \pm 14.21\end{array}$ & $\begin{array}{c}0 \\
3.40 \pm 1.30 \\
7.25 \pm 2.01 \\
13.32 \pm 4.60 \\
32.50 \pm 2.61 \\
65.00 \pm 5.50\end{array}$ & $\begin{array}{c}0 \\
4.30 \pm 1.38 \\
5.71 \pm 1.15 \\
13.08 \pm 5.53 \\
23.91 \pm 2.38 \\
53.08 \pm 7.94\end{array}$ \\
\hline
\end{tabular}

Data are mean \pm S.D. of three independent experiments performed in triplicate

Table 2 Effects of $7 \alpha-, 7 \beta$-hydroxycholesterol and 7-ketocholesterol on mitochondrial transmembrane potential $(\Delta \psi \mathrm{m})$, and cytosolic release of cytochrome $c$

\section{Treatments}

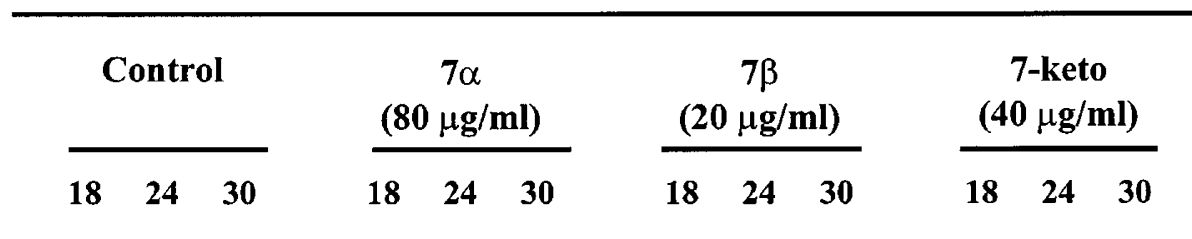

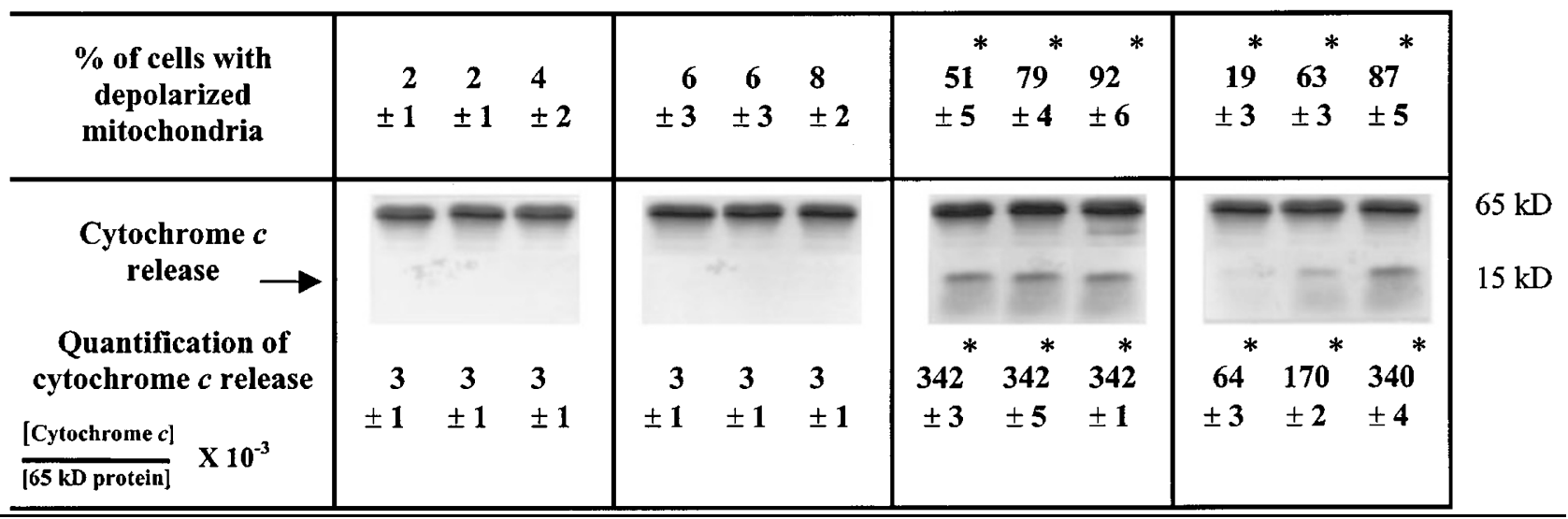

The percentage of cells with depolarized mitochondria resulting from the loss of mitochondrial transmembrane potential $(\Delta \psi \mathrm{m})$ were measured by flow cytometry with the lipophilic dye $\mathrm{DiOC}_{6}(3)$, and the cytosolic release of cytochrome $c(\mathrm{PM}=15 \mathrm{kD})$ was determined by Western blot after 18,24 and $30 \mathrm{~h}$ of treatment, in the absence (control) or in the presence of $80 \mu \mathrm{g} / \mathrm{ml} \mathrm{7 \alpha -hydroxycholesterol}(7 \alpha), 20 \mu \mathrm{g} / \mathrm{ml} 7 \beta$-hydroxycholesterol $(7 \beta)$, and $40 \mu \mathrm{g} / \mathrm{ml}$ 7-ketocholesterol (7-keto). Quantitative analysis of cytochrome $c$ was performed using autoradiography with a Biocom image analysis system and normalized against the $65 \mathrm{kD}$ protein. Data obtained by flow cytometry correspond to three independent experiments performed in triplicate. Data corresponding to cytochrome $c$ release are representative of three independent experiments. ${ }^{*}$ indicates statistically significant differences $(P<0.05)$ between control and oxysterol-treated cells

substrates of caspase-3 during apoptosis is PARP (115 kD), an enzyme that appears to be involved in DNA repair, genome surveillance, and integrity. ${ }^{37}$ So, PARP degradation was also investigated by Western blot analysis of $7 \beta$-hydroxycholesterol $(20 \mu \mathrm{g} / \mathrm{ml})$, and 7-ketocholesterol (40 $\mu \mathrm{g} / \mathrm{ml})$-treated U937 cells taken at 18,24 and $30 \mathrm{~h}$ of incubation. Immunoblot analysis with an antibody recognizing both the full length and the cleaved form of PARP (115 and $85 \mathrm{kD}$ ) revealed an early cleavage of PARP occurring after $18 \mathrm{~h}$ of treatment with $7 \beta$-hydroxycholesterol, whereas in the presence of 7-ketocholesterol, PARP degradation was observed only at 24 and $30 \mathrm{~h}$ of treatment (Table 3 ). In untreated cells, as well as in $7 \alpha$-hydroxycholesterol $(80 \mu \mathrm{g} /$ $\mathrm{ml}$ )-treated cells, no PARP degradation was found regardless of the time of treatment (Table 3 ).

\section{Generation of $\mathrm{C} 16: 0$ and $\mathrm{C} 24: 1$ ceramide species when treated with $7 \beta$-hydroxycholesterol and 7-ketocholesterol}

Ceramide is a group of neutral sphingolipids that mediate several cellular processes ${ }^{38}$ and constitute important sec- 
Table 3 Effects of $7 \alpha-, 7 \beta$-hydroxycholesterol, and 7-ketocholesterol on activation of caspase-9, and -3, and poly(ADP-ribose) polymerase degradation

\section{Treatments}

\begin{tabular}{|c|c|c|c|c|c|c|c|c|c|c|c|}
\hline \multirow[b]{2}{*}{$\begin{array}{c}\text { Time of treatment } \\
\text { (hours) }\end{array}$} & Control & \multicolumn{3}{|c|}{$\begin{array}{c}7 \alpha \\
(80 \mu \mathrm{g} / \mathrm{ml})\end{array}$} & \multicolumn{3}{|c|}{$\begin{array}{c}7 \beta \\
(20 \mu \mathrm{g} / \mathrm{ml})\end{array}$} & \multicolumn{3}{|c|}{$\begin{array}{c}\text { 7-keto } \\
(40 \mu \mathrm{g} / \mathrm{ml})\end{array}$} & \\
\hline & $\begin{array}{lll}18 & 24 & 30\end{array}$ & 18 & 24 & 30 & 18 & 24 & 30 & 18 & 24 & 30 & \\
\hline caspase-9 & --- & - & - & - & 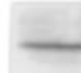 & 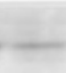 & - & - & - & - & $47 \mathrm{kD}$ \\
\hline caspase-3 & 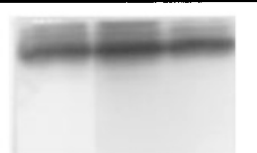 & en & $=$ & $=$ & 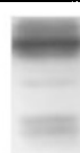 & & 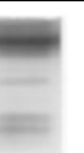 & $=$ & $=$ & 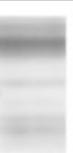 & $\begin{array}{l}32 \mathrm{kD} \\
17 \mathrm{kD}\end{array}$ \\
\hline $\begin{array}{l}\text { caspase-3 activity } \\
\text { (pmol AMC / min) }\end{array}$ & $\begin{array}{ccc}14 & 13 & 18 \\
\pm 2 & \pm 3 & \pm 6\end{array}$ & $\begin{array}{l}15 \\
\pm 6\end{array}$ & $\begin{array}{l}10 \\
\pm 5\end{array}$ & $\begin{array}{r}14 \\
\pm 3\end{array}$ & $\begin{array}{l}{ }^{*} \\
39 \\
\pm 2\end{array}$ & $\begin{array}{r}33 \\
\pm 4\end{array}$ & $\begin{array}{c}* \\
32 \\
\pm 4\end{array}$ & $\begin{array}{r}* \\
46 \\
\pm 3\end{array}$ & $\begin{array}{c}{ }^{*} \\
94 \\
\pm 7\end{array}$ & $\begin{array}{r}* \\
95 \\
\pm 14\end{array}$ & \\
\hline PARP & $x_{-1}$ & & 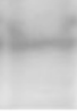 & & 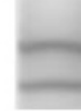 & & 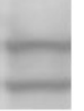 & 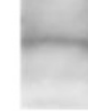 & 5 & & $\begin{array}{l}115 \mathrm{kD} \\
85 \mathrm{kD}\end{array}$ \\
\hline
\end{tabular}

Caspase-9 degradation, caspase-3 cleavage, caspase-3 activity, and poly(ADP-ribose) polymerase (PARP) degradation were investigated by Western blot analysis and fluorogenic assay at 18,24 , and $30 \mathrm{~h}$ of culture in the absence or in the presence of $80 \mu \mathrm{g} / \mathrm{ml} 7 \alpha$-hydrocholesterol $(7 \alpha), 20 \mu \mathrm{g} / \mathrm{ml} 7 \beta$-hydroxycholesterol $(7 \beta)$, and $40 \mu \mathrm{g} /$ $\mathrm{ml}$ 7-ketocholesterol (7-keto). Western blot data are representative of three independent experiments. Data corresponding to caspase-3 activity represent three independent experiments performed in triplicate. ${ }^{*}$ Indicates statistically significant differences $(P<0.05)$ between control and oxysterol-treated cells

ondary messenger molecules mainly in the regulation of cell growth, and in apoptosis signaling. ${ }^{27}$ As cellular ceramide generation is frequently observed after treatment with various apoptosis inducers, ${ }^{39}$ we asked whether ceramide synthesis was upregulated during $7 \beta$-hydroxycholesterol and 7-ketocholesterol-induced apoptosis. To this end, U937 cells were treated for $30 \mathrm{~min}, 1,6,12,18,24$, and $30 \mathrm{~h}$ with $7 \beta$ hydroxycholesterol $(20 \mu \mathrm{g} / \mathrm{ml})$, or 7 -ketocholesterol $(40 \mu \mathrm{g} /$ $\mathrm{ml}$ ), and ceramide species were characterized and quantified by electrospray ionization mass spectrometry. As previously mentioned, the major ceramide species present in U937 cells were $\mathrm{C} 16: 0$ and $\mathrm{C} 24: 1 .^{40}$ The cellular content of these predominant ceramides increased with the time of treatment (Figure 5), whereas there was no generation of any previously undetected ceramide species following cell stimulation at any time (data not shown). Thus, significant increases $(P<0.05)$ of $\mathrm{C} 16: 0$ were observed after 6 and $12 \mathrm{~h}$ of treatment with $7 \beta$ hydroxycholesterol and 7-ketocholesterol, respectively, and with each oxysterol, a plateau was reached at $18 \mathrm{~h}$ of treatment (Figure 5A). Similar profiles were found with C24:1 (Figure 5B). At the plateau, C16:0 and C24:1 content (per cell) were three to four times higher in $7 \beta$ hydroxycholesterol- than in 7-ketocholesterol-treated cells, and C24:1 content (per cell) was always four to five times lower than $\mathrm{C} 16: 0$ content (Figure 5$)$. In untreated cells, as well as in the presence of $7 \alpha$-hydroxycholesterol $(80 \mu \mathrm{g} / \mathrm{ml})$, no ceramide generation was ever observed (Figure 5). Therefore, even at a high concentration $(80 \mu \mathrm{g} / \mathrm{ml}), 7 \alpha-$ hydroxycholesterol is unable to induce apoptosis or to stimulate ceramide generation. As the aim of further experiments was to establish the relationship between apoptosis and ceramide synthesis, the following investigations were only performed on $7 \beta$-hydroxycholesterol- and 7 ketocholesterol-treated cells.

\section{Z-VAD-fmk counteracts $7 \beta$-hydroxycholesterol- and 7-ketocholesterol-induced apoptosis but does not reduce ceramide generation}

The mechanisms by which ceramide generation is related to apoptosis have not yet been fully addressed. Because ceramide accumulation occurred concomitantly with en- 


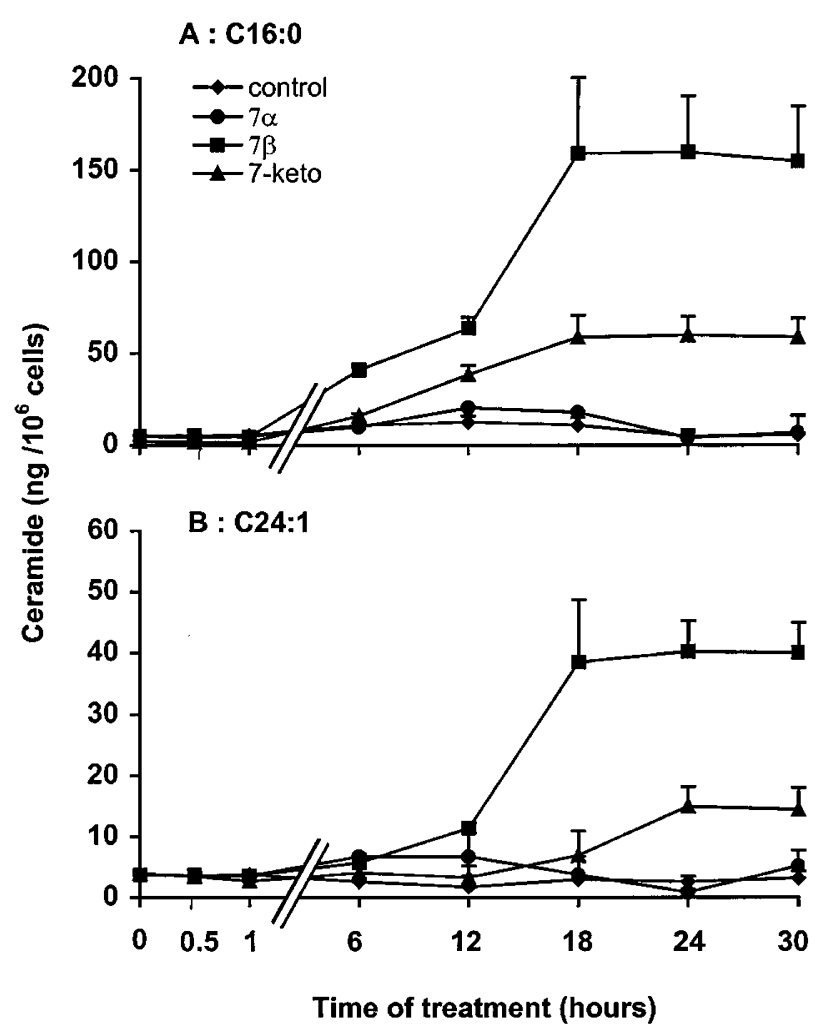

Figure 5 Effects of $7 \alpha-, 7 \beta$-hydroxycholesterol and 7-ketocholesterol on ceramide generation. $\mathrm{C} 16: 0(\mathbf{A})$ and $\mathrm{C} 24: 1$ (B) ceramide changes quantified by electrospray ionization mass spectrometry were studied in U937 cells cultured for $30 \mathrm{~min}, 1,6,12,18,24$, and $30 \mathrm{~h}$ in the absence (control) or in the presence of $7 \alpha$-hydroxycholesterol $(80 \mu \mathrm{g} / \mathrm{ml}), 7 \beta$-hydroxycholesterol $(20 \mu \mathrm{g} /$ $\mathrm{ml})$, or 7 -ketocholesterol $(40 \mu \mathrm{g} / \mathrm{ml})$. Data are mean \pm S.D. of three independent experiments performed in triplicate

hanced caspase-3 activation, which is an important effector caspase with numerous substrates, ${ }^{41,42}$ we asked whether C16:0 and C24:1 ceramide generation depended on caspase-3. To this end, U937 cells were treated for $24 \mathrm{~h}$ with $7 \beta$-hydroxycholesterol $(20 \mu \mathrm{g} / \mathrm{ml})$ or 7 -ketocholesterol $(40 \mu \mathrm{g} / \mathrm{ml})$ in the absence or in the presence of Z-VAD-fmk $(100 \mu \mathrm{M})$, which is a broad spectrum cell-permeable caspase inhibitor. $^{30}$ Taken alone, Z-VAD-fmk did not increase the percentage of apoptotic cells, of propidium iodide permeable cells, or of cells with depolarized mitochondria (cells with low $\Delta \psi_{\mathrm{m}}$ ) (Table 4). Z-VAD-fmk had also no effect on either ceramide generation, caspase- 3 activity, caspase-3 cleavage or PARP degradation (Table 4). When Z-VAD-fmk was added to the culture medium 30 min before $7 \beta$-hydroxycholesterol $(20 \mu \mathrm{g} / \mathrm{ml})$ or 7 -ketocholesterol $(40 \mu \mathrm{g} / \mathrm{ml})$, the percentage of apoptotic cells characterized by condensed and/or fragmented nuclei after staining with Hoechst 33342 was significantly reduced, cleavage in the small subunit of caspase- 3 was completely inhibited, caspase-3 activity was strongly impaired and PARP-degradation was counteracted (Table 4). However, as shown in Table 4, pretreatment of cells with Z-VADfmk had no effect on cell permeability to propidium iodide and on mitochondrial depolarization measured with the cationic lipophilic dye $\mathrm{DiOC}_{6}(3)$. Likewise, C16:0 and C24:1 ceramide generation was similar when the cells were treated with $7 \beta$-hydroxycholesterol- or 7-ketocholesterol in the absence or in the presence of Z-VAD-fmk (Table 4). Thus, Z-VAD-fmk is able to inhibit certain related events that occur during $7 \beta$-hydroxycholesterol- and 7-ketocholesterol-induced apoptosis (morphological changes of the nuclei, induction of caspase-3 activity, cleavage of caspase-3 and PARP degradation), but not cell permeability to propidium iodide, mitochondrial depolarization, and C16:0 and C24:1 ceramide generation. Consequently, in our model of apoptosis, ceramide generation does not depend on caspase-3.

\section{Fumonisin B1 blocks C16:0 and C24:1 ceramide species generation but not $7 \beta$-hydroxycholesterol- and 7-ketocholesterol-induced apoptosis}

Various metabolic pathways can contribute to ceramide synthesis, ${ }^{38,39}$ but the late occurrence of ceramide generation when treated with $7 \beta$-hydroxycholesterol $(20 \mu \mathrm{g} / \mathrm{ml})$ and 7-ketocholesterol $(40 \mu \mathrm{g} / \mathrm{ml})$ rather suggests a stimulation of ceramide synthesis by the enzyme ceramide synthase. ${ }^{43}$ Therefore, U937 cells were treated for $24 \mathrm{~h}$ with $7 \beta$ hydroxycholesterol $(20 \mu \mathrm{g} / \mathrm{ml})$ or 7-ketocholesterol $(40 \mu \mathrm{g} /$ $\mathrm{ml}$ ) in the absence or in the presence of fumonisin B1 $(100 \mu \mathrm{M})$, a specific inhibitor of ceramide synthase. ${ }^{31}$ Under those conditions, similar proportions of apoptotic cells, of propidium iodide permeable cells, and of cells with depolarized mitochondria (characterized by low values of $\Delta \psi_{\mathrm{m}}$ ) were detected in untreated- and in fumonisin B1-treated cells (Table 5). Noteworthy, when fumonisin B1 was added to the culture medium $30 \mathrm{~min}$ before $7 \beta$-hydroxycholesterol $(20 \mu \mathrm{g} /$ $\mathrm{ml}$ ) or 7 -ketocholesterol $(40 \mu \mathrm{g} / \mathrm{ml})$, ceramide generation was strongly reduced but no significant decreases in the percentages of apoptotic cells, of propidium iodide permeable cells, and of cells with depolarized mitochondria were observed (Table 5). Therefore, $7 \beta$-hydroxycholesterol- and 7 ketocholesterol-induced apoptosis does not seem mediated by a de novo pathway of C16:0 and C24: 1 ceramide species generation involving ceramide synthase. In addition, our data also suggest that $\mathrm{C} 16: 0$ and $\mathrm{C} 24: 1$ ceramide species generation through ceramide synthase activity is not involved in the occurrence of cell permeability to propidium iodide and in the loss of transmembrane mitochondrial potential $\left(\Delta \psi_{\mathrm{m}}\right)$.

\section{Discussion}

Due to the fundamental role of apoptosis in physiological and in pathological processes, it is of importance to identify the molecules capable of inducing this form of cell death and to characterize their mechanisms. ${ }^{33,44}$ Among these proapoptotic molecules, oxysterols (which are oxygenated derivatives of cholesterol, and which result from the oxidation of cholesterol essentially on its B ring or on its side chain) constitute a wide class of compounds ${ }^{1,3}$ that could be involved in Alzheimer's disease ${ }^{45}$ and that probably play a key role in the initiation and in the development of atherosclerosis. ${ }^{46}$ Indeed, some of them, such as $7 \beta$-hydroxycholesterol and 7ketocholesterol are potent inducers of apoptosis in tumoral and normal cells, ${ }^{14,47,48}$ especially those of the nervous system $^{49-51}$ and of the vascular wall. ${ }^{12}$ As $7 \alpha$-hydroxycho- 
Table 4 Effects of z-VAD-fmk on the proportions of apoptotic cells, propidium iodide permeable cells, and cells with depolarized mitochondria, on ceramide generation, caspase-3 activity, caspase-3 cleavage, and poly(ADP-ribose) polyermase degradation

\section{Treatments}

(24 h)

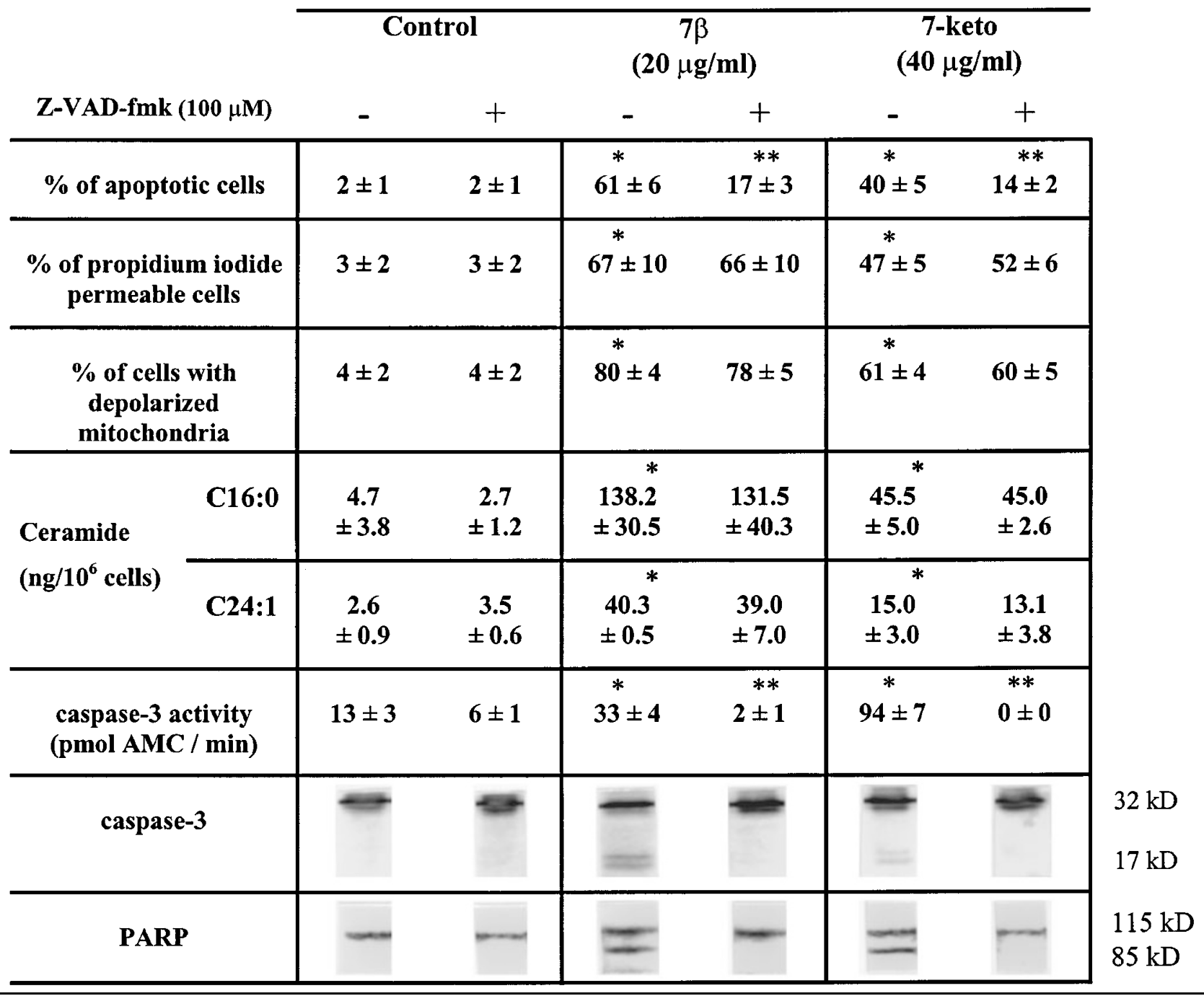

The proportions of apoptotic cells, propidium iodide permeable cells, and cells with depolarized mitochondria, as well as ceramide generation (C16:0 and C24:1 ceramide species), caspase-3 activity, caspase-3 cleavage, and poly(ADP-ribose) polymerase (PARP) degradation were investigated at $24 \mathrm{~h}$ of culture in the absence or in the presence of $20 \mu \mathrm{g} / \mathrm{ml} 7 \beta$-hydroxycholesterol $(7 \beta)$, and $40 \mu \mathrm{g} / \mathrm{ml}$ 7-ketocholesterol (7-keto), with or without Z-VAD-fmk (100 $\mu \mathrm{M})$. Proportions of apoptotic cells, propidium iodide permeable cells, cells with depolarized mitochondria, C16:0 and C24:1 ceramide species content, and caspase-3 activity correspond to three independent experiments performed in triplicate. Western blot data are representative of three independent experiments. *Indicates statistically significant differences $(P<0.05)$ between control and oxysterol-treated cells; **Indicates statistically significant differences $(P<0.05)$ between oxysterol-treated cells and (oxysterol+Z-VAD-fmk)treated cells

lesterol is not cytotoxic, the biological effects of oxysterols oxidized at $\mathrm{C} 7$ ( $7 \alpha$-, $7 \beta$-hydroxycholesterol, and 7-ketocholesterol) seem tightly regulated, and it was therefore of interest to compare, and to characterize their cytotoxic effects. To this end, human U937 promyelocytic leukemia cells were treated with oxysterol oxidized at C7 at concentrations $(5-80 \mu \mathrm{g} / \mathrm{ml})$ that were in the range of levels measured in the plasma of hypercholesterolemic patients ${ }^{52}$ and of cholesterol-rich fed rabbits. ${ }^{53}$ U937 cells were chosen because they are sensitive to oxysterols in the same range of concentrations as those observed in nerve cells ${ }^{49,50}$ as well as in endothelial and smooth muscle cells. ${ }^{12}$ In addition, U937 cells are frequently used as macrophage-like reference models to investigate the cytotoxicity of oxysterols in humans, ${ }^{9,14,15}$ as it is well admitted that macrophages play an important role in the atherosclerotic process. ${ }^{47}$

Under those conditions, with the use of different criteria (cell counting, permeability to propidium iodide, morphological aspect of cellular nuclei, mitochondrial depolarization, cytochrome $c$ release into the cytosol, caspase- 9 and -3 activation, PARP degradation, quantification and characterization of ceramide species) we report that $7 \alpha$-hydroxycho- 
Table 5 Effects of fumonisin B1, a specific inhibitor of ceramide synthase, on the proportions of apoptotic cells, propidium iodide permeable cells, cells with depolarized mitochondria and on ceramide generation

\begin{tabular}{|c|c|c|c|c|c|c|}
\hline \multirow[b]{3}{*}{ Fumonisin B1 (100 $\mu \mathrm{M})$} & \multicolumn{6}{|c|}{ Treatments (24 h) } \\
\hline & \multicolumn{2}{|c|}{ Control } & \multicolumn{2}{|c|}{$7 \beta(20 \mu \mathbf{g} / \mathbf{m l})$} & \multicolumn{2}{|c|}{ 7-keto $(40 \mu \mathrm{g} / \mathrm{ml})$} \\
\hline & - & + & - & + & - & + \\
\hline Apoptotic cells (\%) & $2 \pm 1$ & $2 \pm 1$ & $61 \pm 6^{\star}$ & $55 \pm 5$ & $40 \pm 5^{\star}$ & $35 \pm 3$ \\
\hline Propidium iodide permeable cells (\%) & $3 \pm 2$ & $4 \pm 3$ & $67 \pm 10^{*}$ & $78 \pm 6$ & $47 \pm 5^{\star}$ & $46 \pm 6$ \\
\hline Cells with depolarized mitochondria (\%) & $4 \pm 2$ & $4 \pm 3$ & $77 \pm 4^{*}$ & $69 \pm 5$ & $64 \pm 5^{\star}$ & $65 \pm 2$ \\
\hline \multicolumn{7}{|l|}{ Ceramide (ng/10 6 cells) } \\
\hline C16:0 & $4.7 \pm 3.8$ & $1.2 \pm 3.0$ & $138.2 \pm 30.5^{\star}$ & $10.5 \pm 5.0^{\star \star}$ & $45.5 \pm 5.0^{\star}$ & $9.2 \pm 2.6^{\star *}$ \\
\hline C24:1 & $2.6 \pm 0.9$ & $1.3 \pm 0.6$ & $40.3 \pm 0.5^{\star}$ & $6.7 \pm 3.0^{\star \star}$ & $15.0 \pm 3.0^{\star}$ & $5.0 \pm 1.5^{\star *}$ \\
\hline
\end{tabular}

The proportions of apoptotic cells, propidium iodide permeable cells, and cells with depolarized mitochondria, as well as ceramide generation (C16:0 and C24:1 ceramide species) were investigated at $24 \mathrm{~h}$ of culture in the absence or in the presence of $20 \mu \mathrm{g} / \mathrm{ml} 7 \beta$-hydroxycholesterol $(7 \beta)$, and $40 \mu \mathrm{g} / \mathrm{ml} 7$-ketocholesterol $(7$ keto), with or without fumonisin B1 (100 $\mu \mathrm{M})$. Proportions of apoptotic cells, propidium iodide permeable cells, cells with depolarized mitochondria, and C16:0 and C24:1 ceramide species content correspond to three independent experiments performed in triplicate. ${ }^{*}$ Indicates statistically significant differences $(P<0.05)$ between control and oxysterol-treated cells; ${ }^{* *}$ Indicates statistically significant differences $(P<0.05)$ between oxysterol-treated cells and (oxysterol+fumonisin B1)-treated cells

lesterol induces only a slight inhibition of cell growth, and that the apoptotic potency is higher with $7 \beta$-hydroxycholesterol than with 7-ketocholesterol, although these oxysterols trigger similar signaling pathways.

So, as reported before on a wide variety of normal or tumoral cell types deriving from the digestive, immune, nervous and cardiovascular systems, ${ }^{11,49,54,55}$ the present in vitro investigation underlines again the important differences of toxicity from one oxysterol to another even when these compounds are structurally identical as $7 \alpha$ - and $7 \beta$-hydroxycholesterol. Noteworthy, as no cytoxicity of $7 \alpha$ hydroxycholesterol was previously observed on lymphoma and hepatoma cells, ${ }^{56,57}$ the present investigation suggests that the activity of this compound would not depend on the cell type considered as is frequently the case with some oxysterols. Thus, 25-hydroxycholesterol displays slight cytotoxic activities towards lymphoma and hepatoma cells as well as towards endothelial cells, but it is strongly cytotoxic against microglial cells while $7 \beta$-hydroxycholesterol acts in the opposite manner. ${ }^{11,49,56,57}$ Moreover, our data also confirm the important cytotoxic effects of $7 \beta$-hydroxycholesterol and of 7-ketocholesterol that were described to induce either apoptosis or necrosis according to the cells considered, ${ }^{12,55}$ and they raise further the interest in determining the cell death characteristics linked to these compounds.

In the present work, in agreement with our previous studies, ${ }^{9,15}$ we also report that $7 \beta$-hydroxycholesterol and 7-ketocholesterol- induced cell death is a form of apoptosis characterized by a reduction of cell growth, an enhanced permeability to propidium iodide (which is in agreement with the alterations of the physical properties of lipid membranes observed in the presence of various oxysterols by angleresolved fluorescence depolarization microscopy and electron spin resonance), ${ }^{58}$ and an increased proportion of cells with condensed and/or fragmented nuclei. The significant reduction of cell growth associated with a marked increase permeability to propidium iodide occuring during treatment with $7 \beta$-hydroxycholesterol and 7-ketocholesterol is probably a complex phenomenon that could be the consequence of the simultaneous downregulation of proliferation signals and of the complete disruption of cellular structures in late steps of the apoptotic process, as it is frequently the case with various pro-apoptotic compounds. ${ }^{59}$ Similarly, the occurrence of cells with fragmented and/or condensed nuclei, which is a characteristic feature of apoptosis, ${ }^{23}$ also involves complex signaling pathways that have not yet been completely delineated, and a variety of models associated with apoptotic morphology have been described. ${ }^{21}$ Nowadays, three compartments are implicated in the execution of apoptotic processes; $^{60}$ these compartments are the plasma membrane where both death and survival receptors reside, the mitochondrion, which is home for several proteins that regulate apoptosis, and the endoplasmic reticulum involving caspase-12. ${ }^{33,60,61}$ When treated with $7 \beta$-hydroxycholesterol and 7-ketocholesterol, the loss of the mitochondrial trasmembrane potential $\left(\Delta \psi_{\mathrm{m}}\right)$ and the simultaneous release of cytochrome $c$ into the cytosol show that the mitochondrial compartment is involved in the apoptotic process, and the requirement of these mitochondrial events in the induction of the downstream biochemical changes leading to caspase- 9 and -3 activation, and to PARP degradation, is suggested by the ability of various antioxidants (glutathion, $\mathrm{N}$-acetylcysteine, and vitamin $\mathrm{E}$ ) to counteract 7-ketocholesterol-induced cell death. ${ }^{15,62}$ Indeed, we previously demonstrated that impairment of 7ketocholesterol-induced apoptosis by glutathion, $\mathrm{N}$-acetylcysteine and vitamin $E$ correlates with the prevention of mitochondrial dysfunctions, i.e, loss of the trasmembrane mitochondrial potential $\left(\Delta \psi_{\mathrm{m}}\right)$ and simultaneous release of cytochrome $c$ into the cytosol. ${ }^{62}$ Therefore, there is considerable evidence that the disruption of mitochondrial functions are major events in $7 \beta$-hydroxycholesterol and 7ketocholesterol-induced apoptosis. In addition, similarly to numerous inducers of apoptosis, ${ }^{34,63} 7 \beta$-hydroxycholesterol and 7-ketocholesterol also induce an apoptotic mode of cell death where casapases play important roles. Indeed, we report in the present study that Z-VAD-fmk (a broadspectrum caspase inhibitor $)^{30}$ counteracts the cleavage and activity of caspase-3, and consequently PARP degradation and morphological changes associated with apoptosis (occurence of cells with fragmented and / or condensed nuclei). However, Z-VAD-fmk does not inhibit the loss of 
transmembrane mitochondrial potential and the permeability to propidium iodide known to enter only in dead cells. ${ }^{32}$ Therefore, in oxysterol-induced apoptosis as in numerous other types of apoptotic processes, ${ }^{64}$ the inhibition of casapases-dependent events by Z-VAD-fmk is not sufficient to inhibit the commitment to cell death. Taken together these different data led us to speculate that $7 \beta$-hydroxycholesterol and 7-ketocholesterol would trigger the following post-mitochondrial cascade of events: cytochrome $c$ release into the cytosol would contribute to the activation of a complex of apoptosis activating factor 1 (Apaf-1) and of pro-caspase-9, leading to the cytochrome $c$ dependent processing of pro-caspase-3 which in turn would cleave several death substrates including poly (ADP-ribose) polymerase (PARP). ${ }^{33,65,66}$

Because cell signals upstream of mitochondrial dysfunctions resulting from $7 \beta$-hydroxycholesterol and 7-ketocholesterol-induced apoptosis are yet unknown, and since some ceramide species that play an important role in the transduction of the apoptotic signal ${ }^{27,38}$ were also found to induce mitochondrial dysfunctions such as loss of mitochondrial transmembrane potential and cytochrome $c$ release, ${ }^{67-69}$ we further investigated changes of ceramide concentration (per cell) after various treatment times in the presence of $7 \beta$-hydroxycholesterol and 7-ketocholesterol. The present study is consistent with the findings that the predominant ceramide species present in $U 937$ cells are C16: 0 and $\mathrm{C} 24: 1,{ }^{40}$ and it demonstrates with the use of ZVAD-fmk that ceramide generation occurring in U937 cells following treatment with $7 \beta$-hydroxycholesterol and 7ketocholesterol does not depend on caspase activation, especially activation of caspase-3, which is an important effector caspase with numerous substrates. ${ }^{42}$ Indeed, in U937 cells incubated with 7 $\beta$-hydroxycholesterol (or 7ketocholesterol), activation of caspase-3 was inhibited and the percentage of cells with fragmented and/or condensed nuclei characteristic of apoptotic cells was reduced in the presence of Z-VAD-fmk whereas the accumulation of C16:0 and C24:1 ceramide species was not modified. In addition, the present work underlines that ceramide generation occuring during treatment with $7 \beta$-hydroxycholesterol and 7-ketocholesterol (but not with $7 \alpha$-hydroxycholesterol) is mediated through ceramide synthase, as it is in daunorubicin-induced apoptosis in hen granulosa cells, ${ }^{70}$ in CPT-11-induced apoptosis in L929 cells, ${ }^{71}$ and in 12-Otetradecanoylphorbol-13-acetate-induced apoptosis in LNCaP cells. ${ }^{72}$ So, in $U 937$ cells, hen granulosa cells, L929 cells, and LNCaP cells, incubated in the presence of oxysterol, daunorubicin, CPT-11, and 12-O-tetradecanoylphorbol-13-acetate, respectively, it was possible to abrogate ceramide accumulation with fumonisin B1, a fungal toxin that specifically inhibits ceramide synthase. ${ }^{31}$ However, contrary to the data obtained for daunorubicin-, CPT11-, and 12-O-tetradecanoylphorbol-13-acetate-treated cells, abrogation of ceramide generation in oxysteroltreated cells did not abolish apoptosis. Therefore, as in the case of apoptosis triggered by oxidized low density lipoproteins ${ }^{73}$ which are known to contain high levels of $7 \beta$ hydroxycholesterol and of 7-ketocholesterol, ${ }^{74}$ our results rather suggest that ceramide generation (especially $\mathrm{C} 16: 0$ and C24: 1 ceramide species) is not a main event in the death response to $7 \beta$-hydroxycholesterol and 7-ketocholesterol probably because ceramide generation (in our model of cell death) has minor effects on central executioners of the apoptotic process such as mitochondria. Indeed, fumonisin B1, which strongly reduces the accumulation of C16:0 and C24:1 ceramide species induced by 7 $\beta$ hydroxycholesterol and 7-ketocholesterol, does not prevent the loss of transmembrane mitochondrial potential $\left(\Delta \psi_{\mathrm{m}}\right)$. In addition, our results also suggest that $\mathrm{C} 16: 0$ and $\mathrm{C} 24: 1$ ceramide species are probably not involved in the regulation of cell permeability to propidium iodide since fumonisin B1, which strongly inhibits ceramide generation triggered by $7 \beta$-hydroxycholesterol or by 7 -ketocholesterol, does not simultaneously reduce the proportion of propidium iodide permeable cells. In support of the idea that ceramide generation is however implied in the control of several cellular activities particularly in apoptotically dying cells, ${ }^{38}$ further studies are therefore needed to clarify the role of ceramide generation during oxysterol-induced cell death. However, as some oxysterols such as 25-hydroxycholesterol $^{75}$ and $7 \beta$-hydroxycholesterol ${ }^{76}$ have been shown to favor the accumulation of the cells in the G0/G1 phase of the cell cycle, and as increase ceramide generation has been described in yeast ${ }^{77}$ as well as in Molt- 4 cells $^{78}$ blocked in G1, we can suppose a link between ceramide generation and regulation of the cell cycle during oxysterolinduced apoptosis.

Noteworthy, contrary to $7 \beta$-hydroxycholesterol and 7ketocholesterol, no cytoxicity was observed in the presence of $7 \alpha$-hydroxycholesterol, and the only cellular dysfunction identified was a slight inhibition of cell growth at the highest concentration considered $(80 \mu \mathrm{g} / \mathrm{ml})$. As all oxysterols oxidized at C7 (7 $\alpha$-hydroxycholesterol, $7 \beta$-hydroxycholesterol and 7-ketocholesterol) accumulate inside the cells, the differences of activity between $7 \alpha$-hydroxycholesterol and $7 \beta$-hydroxycholesterol, which are structurally analogous but stereologically different, suggest that the biological activities of oxysterols oxidized at C7 are probably mediated by a receptor. Nowadays, various kinds of oxysterol binding molecules have been identified but nothing is known about their ability to trigger an apoptotic signal. Among these molecules, some studies revealed that several oxysterols can bind to the antiestrogen-binding site (AEBS) located predominantly in the microsomal fraction, and ubiquitously distributed in animal and human tissues. ${ }^{79}$ However, as the affinities of oxysterols oxidized at $\mathrm{C} 7$ for the AEBS are in the following order ( $7 \alpha$-hydroxycholesterol $>7$-ketocholesterol $>7 \beta$-hydroxycholesterol), we can suppose that this receptor does not deliver a death signal. ${ }^{80}$ Another putative receptor of oxysterols is the oxysterol-binding protein (OSBP) present in the cytosol of many cell types, ${ }^{81}$ whose gene has been mapped to the long arm of human chromosome 11 and the proximal end of mouse chromosome 19. ${ }^{82}$ However, $7 \alpha$-hydroxycholesterol, $7 \beta$-hydroxycholesterol, and 7-ketocholesterol are weakly recognized by this receptor, contrary to the cholesterol derivatives hydroxylated on the side chain. ${ }^{83}$ Therefore, OSBP is probably not involved in the apoptotic process induced by $7 \beta$-hydroxycholesterol and 7-ketocholesterol. As it was 
shown that sterols derived from cholesterol by the introduction of a second functional group (hydroxyl or ketone) in the $6,7,15,20,22,24$, or 25 positions are potent inhibitors of 3-hydroxy-3-methylglutaryl coenzyme A reductase (HMG-CoA reductase), ${ }^{84}$ and that some statins (synthetic inhibitors of HMG-CoA reductase) ${ }^{85}$ can induce an apoptotic mode of cell death, ${ }^{86,87}$ the different potency of oxysterols oxidized at $\mathrm{C} 7$ to induce apoptosis might also depend on their ability to inhibit HMG-CoA reductase. Indeed, HMG-CoA reductase activity has major consequences on the transmission of growth factor-dependent survival signals by contributing to the synthesis of farnesylpyrophosphate, which is not only a cholesterol precursor but also an intermediate in different isoprenoiddependent metabolic pathways such as dolichol and ubiquinone synthesis, but also protein farnesylation (Ras) and protein geranyl-geranylation (Rho, Rab), which seem essential for the delivery of anti-apoptotic signals through pathways involving the activation of phosphatidylinositol-3kinase $(\mathrm{PI}(3) \mathrm{K})$ and of its downstream effector, the serine / threonine kinase Akt. ${ }^{87-91}$ So, if we suppose that $7 \alpha$ hydroxycholesterol, contrary to $7 \beta$-hydroxycholesterol and 7-ketocholesterol, is not a potent inhibitor of HMG-CoA reductase, it could subsequently not induce a suppression of Ras farnesylation and of Rho geranyl-geranylation. In turn, according to this hypothesis, $7 \alpha$-hydroxycholesterol could not lead to the suppression of phosphorylation through the pathway involving the activation of $\mathrm{PI}(3) \mathrm{K} / \mathrm{Akt}$. As a consequence, numerous molecules such as Bad or Bax would not be dephosphorylated and could not interact with $\mathrm{Bcl}-2$ at the mitochondrial level ${ }^{92-94}$ to induce a loss of transmembrane mitochondrial potential $\left(\Delta \psi_{\mathrm{m}}\right)$, cytosolic release of cytochrome $c$, activation of caspases-9 and -3 , and PARP degradation. More recently, new receptors (LXRs) have been identified, and two of them, the closely related transcription factors $\mathrm{LXR} \alpha$ and $\mathrm{LXR} \beta$, are activated by hydroxylated cholesterol as ligands, ${ }^{95,96}$ but their roles in oxysterol-induced cell death remain to be defined. However, it seems that these receptors are involved in the activation of SREB-1, which results from the cleavage of sterol regulatory element binding proteins (SREBP) under the action of CPP32/SCA-1, ${ }^{97,98}$ reinforcing the hypothesis that molecules implied in cholesterol biosynthesis and lipoprotein uptake are probably implied in the program of apoptosis.

In conclusion, our data underline the complexity of the mechanisms of oxysterols oxidized at C7 ( $7 \alpha$-hydroxycholesterol, $7 \beta$-hydroxycholesterol and 7-ketocholesterol), and they demonstrate the following points: (1) induction of apoptosis depends on the radical (hydroxyl or keto) present at $\mathrm{C} 7$ as well as on the $\alpha$ or $\beta$ hydroxyl radical position; thus, $7 \beta$-hydroxycholesterol and 7-ketocholestrol are potent inducers of apoptosis but $7 \alpha$-hydroxycholesterol is not; (2) the mitochondrial signaling pathway involving loss of the mitochondrial transmembrane potential $\left(\Delta \psi_{\mathrm{m}}\right)$, release of cytochrome $c$, activation of caspase- 9 and -3 , and PARP degradation is a common feature of $7 \beta$-hydroxycholesteroland 7-ketocholesterol-induced apoptosis; (3) C16:0 and C24:1 ceramide species are generated under treatment with $7 \beta$-hydroxycholesterol and 7-ketocholesterol (but not with $7 \alpha$-hydroxycholesterol); (4) Z-VAD-fmk counteracts $7 \beta$ hydroxycholesterol- and 7-ketocholesterol-induced apoptosis but does not reduce $\mathrm{C} 16: 0$ and $\mathrm{C} 24: 1$ ceramide species generation; (5) the inhibition of significant amounts of $\mathrm{C} 16: 0$ and $\mathrm{C} 24: 1$ ceramide species by fumonisin B1 is not associated with an impairment of $7 \beta$-hydroxycholesterol and of 7-ketocholesterol-induced apoptosis. Thus, the present comparative study performed on oxysterols oxidized at $\mathrm{C} 7$ brings new insights on the metabolic pathways involved in oxysterol-induced apoptosis, and further understanding of the cytotoxicity of oxysterols, which probably play important roles in atherosclerosis, ${ }^{46}$ might allow for the development of new systemic therapies for this disease.

\section{Materials and Methods}

\section{Cells}

U937 cells were grown in suspension in culture medium consisting of RPMI 1640 medium (Gibco, Eragny, France), 2 mM L-glutamine (Gibco), antibiotics (100 U/ml penicillin, $100 \mathrm{mg} / \mathrm{ml}$ streptomycin) (Gibco) and supplemented with $10 \%(\mathrm{v} / \mathrm{v})$ heat-inactived fetal calf serum (Gibco). The cells were seeded at $5 \times 10^{5}$ per $\mathrm{ml}$ of culture medium, passaged twice a week, and incubated at $37^{\circ} \mathrm{C}$ under a $5 \%$ $\mathrm{CO}_{2} / 95 \%$ air atmosphere.

\section{Cell treatments}

The purity of $7 \alpha-, 7 \beta$-hydroxycholesterol (purchased from Steraloids, Wilton, USA), and 7-ketocholesterol (Sigma-Aldrich, L'Isles d'AbeauChesnes, France) was determined to be $100 \%$ by gaseous phase chromatography-mass spectrometry. For all experiments, initial solutions of $7 \alpha-, 7 \beta$-hydroxycholesterol and 7 -ketocholesterol were prepared extemporaneously at a concentration of $800 \mu \mathrm{g} / \mathrm{ml}$ as previously described. ${ }^{15}$ The initial oxysterol solutions were prepared dissolving $800 \mu \mathrm{g}$ of oxysterol in $50 \mu \mathrm{l}$ of absolute ethanol, $950 \mu \mathrm{l}$ of culture medium were further added, and the solution was sonicated. $7 \alpha-, 7 \beta$-hydroxycholesterol and 7 -ketocholesterol were studied at final concentrations of $5,10,20,40$, and $80 \mu \mathrm{g} / \mathrm{ml}(12.5-200 \mu \mathrm{M})$ by adding $6.25,12.5,25,50$, or $100 \mu \mathrm{l}$ of the initial oxysterol solution $(800 \mu \mathrm{g} / \mathrm{ml})$ per $\mathrm{ml}$ of culture medium. The oxysterol concentrations used are in the range of levels measured in the plasma of hypercholesterolemic patients ${ }^{52}$ and of cholesterol-rich fed rabbits. ${ }^{53}$ Under these experimental conditions, the ethanol concentration in the culture medium did not exceed $0.5 \%$. In those conditions, ethanol had no effect on cell growth nor on cell viability measured with propidium iodide, and did not increase the proportion of apoptotic cells when compared to untreated cells. ${ }^{12}$ All oxysterols were introduced in the culture medium at the beginning of the culture. N-benzyloxycarbonyl-valinyl-alaninyl-aspartyl fluoromethylketone (Z-VAD-fmk) (Bachem Biochimie, Voisins-le-Bretonneux, France), which is a broad spectrum cell-permeable caspase inhibitor, ${ }^{30}$ was dissolved in dimethylsulfoxide (Sigma) to a concentration of $2 \mathrm{mM}$, and added to the culture medium at a final concentration of $100 \mu \mathrm{M}$. As for fumonisin B1 (Sigma), a specific inhibitor of ceramide synthase, ${ }^{31}$ it was dissolved in sterile saline $(0.9 \%)$ to a concentration of $500 \mu \mathrm{M}$ and used at a final concentration of $100 \mu \mathrm{M}$. When the cells were simultaneously treated with an oxysterol and with Z-VAD-fmk (or with fumonisin B1), the latter compound was introduced in the culture medium 30 min before the oxysterol. 


\section{Cell counting}

Cell counting was performed with a hemacytometer under a Laborlux IX 70 inverted phase contrast microscope (Olympus, Tokyo, Japan) on cells seeded in 6-well plates (Falcon / Becton Dickinson, Plymouth, UK) at a concentration of $1.5 \times 10^{6}$ cells in $3 \mathrm{ml}$ of culture medium per well.

\section{Identification and quantification of apoptotic cells after nuclei staining with Hoechst $\mathbf{3 3 3 4 2}$}

Nuclear morphology of control and treated cells was studied by fluorescence microscopy after staining with Hoechst 33342 ( $\lambda$ Ex max: $346 \mathrm{~nm}, \lambda \mathrm{Em}$ max: $420 \mathrm{~nm}$ ) (Sigma). Apoptotic cells were characterized by nuclear condensation of chromatin and/or nuclear fragmentation. ${ }^{23}$ Hoechst 33342 was freshly prepared in distilled water at $1 \mathrm{mg} /$ $\mathrm{ml}$ and used at the final concentration of $10 \mu \mathrm{g} / \mathrm{ml}$. After $30 \mathrm{~min}$ of incubation at $37^{\circ} \mathrm{C}$, cells were washed twice in cold PBS and resuspended to a concentration of $10^{6}$ cells $/ \mathrm{ml}$ in PBS containing $1 \%$ (w/v) paraformaldehyde. Cell deposits of about 40000 cells were applied to glass slides by cytocentrifugation for $5 \mathrm{~min}$ at 1000 r.p.m. with a cytospin 2 (Shandon, Cheshire, UK), mounted in Fluoprep (Biomérieux, Marcy l'Etoile, France), and stored in the dark at $4^{\circ} \mathrm{C}$. The morphological aspect of cell nuclei was observed with an Axioskop light microscope (Zeiss, Jena, Germany) by using UV light excitation. Images were acquired with an image analysis system (Biocom, Les Ulis, France), and 300 cells were examined for each sample.

\section{Transmission electron microscopy}

For transmission electron microscopy, $20 \times 10^{6}$ cells were fixed for $1 \mathrm{~h}$ with $2 \%$ glutaraldehyde prepared in a $0.1 \mathrm{M}$ cacodylate buffer ( $\mathrm{pH} 7.4$ ), postfixed in osmium tetroxide, deshydrated using a graded ethanol series, and embedded in Epon. Sections were stained with uranyl acetate and lead citrate, and were examined with a $\mathrm{H} 600$ electron microscope (Hitachi, Tokyo, Japan).

\section{Determination of cell permeability with propidium iodide}

Cell permeability was determined after staining with the phenanthrene dye propidium iodide ( $\lambda E x$ max: $540 \mathrm{~nm}, \lambda E m$ max: $625 \mathrm{~nm}$ ) (Sigma), which enters only dead cells. ${ }^{32}$ A stock solution of propidium iodide was prepared in phosphate-buffered saline (PBS) at the concentration of $10 \mu \mathrm{g} / \mathrm{ml}$, and kept in the dark at room temperature. Propidium iodide was used at a final concentration of $4 \mu \mathrm{g} / \mathrm{ml}$ in a cell suspension adjusted to $10^{6}$ cells $/ \mathrm{ml}$. Fluorescence was immediately quantified by flow cytometry in 10000 cells on a logarithmic scale of fluorescence of four decades of log on a FACScan flow cytometer (Becton Dickinson, Moutain View, CA, USA) at excitation and emission wavelengths of 488 and $585 / 42 \mathrm{~nm}$, respectively.

\section{Characterization and quantification of oxysterols by capillary gas chomatography and mass spectrometry}

U937 cells incubated for $24 \mathrm{~h}$ in their culture medium in the absence or presence of $7 \alpha-, 7 \beta$-hydroxycholesterol or 7 -ketocholesterol used at concentrations of $5,10,20,40$ and $80 \mu \mathrm{g} / \mathrm{ml}$ for $24 \mathrm{~h}$ were collected by centrifugation $\left(1000 \times \mathrm{g}, 4^{\circ} \mathrm{C}, 10 \mathrm{~min}\right)$, washed twice in PBS, and enumerated with a hemacytometer. Total lipids from cells were further extracted by the methods of Folch et al. ${ }^{99}$ The extract was saponified at $60^{\circ} \mathrm{C}$ for $60 \mathrm{~min}$ with potassium hydroxide $(13.2 \mathrm{~g} / \mathrm{l})$, followed by esterification at $60^{\circ} \mathrm{C}$ for $60 \mathrm{~min}$ with boron trifluoride (BF3)-methanol to yield fatty acid methyl esters, and oxysterols were analyzed by capillary gas chromatography ${ }^{24}$ on a $30 \times 0.25 \mathrm{~mm}$ Hewlett-Packard HP5MS column with the use of a Hewlett-Packard 6890 gas chromatograph attached to a 5973 A mass detector (HewlettPackard, Palo Alto, CA, USA). Heptadecanoic acid (17:0) was added as an internal standard to each sample before extraction and the oxysterol content was determined from the ratio of the peak area of the sample to the peak area of the internal standard. Data are represented as the quantity of $7 \alpha-, 7 \beta$-hydroxycholesterol and 7 ketocholesterol in $\mu \mathrm{g}$ per $10^{6}$ cells.

\section{Characterization and quantification of ceramide by electrospray ionization mass spectrometry}

Ceramide changes were studied in U937 cells cultured for 30 min, 1, 6, $12,18,24$, and $30 \mathrm{~h}$ in the absence or in the presence of $7 \alpha$ hydroxycholesterol ( $80 \mu \mathrm{g} / \mathrm{ml}), 7 \beta$-hydroxycholesterol $(20 \mu \mathrm{g} / \mathrm{ml})$, or 7 ketocholesterol $(40 \mu \mathrm{g} / \mathrm{ml})$. In addition, the effects of Z-VAD-fmk $(100 \mu \mathrm{M})$ and of fumonisin $\mathrm{B} 1(100 \mu \mathrm{M})$ were investigated at $24 \mathrm{~h}$ of treatment in the presence of $7 \beta$-hydroxycholesterol $(20 \mu \mathrm{g} / \mathrm{ml})$, or 7 ketocholesterol $(40 \mu \mathrm{g} / \mathrm{ml})$. At the end of the incubation time, cells were collected by centrifugation $\left(1000 \times g, 4^{\circ} \mathrm{C}, 10 \mathrm{~min}\right)$, washed twice in culture medium without fetal calf serum, and enumerated with a hemacytometer. Cells were further lysed in $\mathrm{CH}_{3} \mathrm{OH} / \mathrm{H}_{2} \mathrm{O} / 12 \mathrm{M} \mathrm{HCl}$ 95:5: $0.5(\mathrm{v} / \mathrm{v})$, and sonicated. Lipids were extracted with $\mathrm{CHCl}_{3}$ according to the method described by Gu et al., ${ }^{100}$ and Nacetylsphingosine (ICN, Costa Mesa, CA, USA) was used as internal standard for ceramides. Lipids were eluted by liquid chromatography on a $2.0 \times 250 \mathrm{~mm}$ Hypersil ODS column (Hewlett-Packard) using $5 \mathrm{mM}$ amonium acetate in $\mathrm{CH}_{3} \mathrm{OH}$ as eluant at a flow rate of $0.5 \mathrm{ml} /$ min, and ceramides were characterized by positive ion electrospray ionization mass spectrometry performed on a MSD 1100 mass spectrometer (Hewlett-Packard). The orifice voltage was operated at $80 \mathrm{~V}$, the capillary voltage at $3.5 \mathrm{kV}$, and the drying gas flow at $8 \mathrm{l} / \mathrm{min}$. lons at $\mathrm{m} / \mathrm{z} 324,520$, and 630 were used to measure $\mathrm{N}$ acetylsphingosine, palmitoylsphingosine, and nervonoylsphingosine. Palmitoylsphingosine, and nervonoylsphingosine levels were determined by comparison with a standard curve produced using known amounts of palmitoylsphingosine (Sigma), and nervonoylsphingosine (Sigma). Data are represented as the quantity of ceramide (C16:0 and C24:1) in ng per $10^{6}$ cells.

\section{Flow cytometric measurement of the mitochondrial transmembrane potential $\left(\Delta \psi_{\mathrm{m}}\right)$ with the cationic lipophilic dye $\mathrm{DiOC}_{6}(3)$}

The mitochondrial transmembrane potential $\left(\Delta \psi_{\mathrm{m}}\right)$ was measured with 3, 3'-dihexyloxacarbocyanine iodide $\left(\mathrm{DiOC}_{6}(3)\right.$ : $\lambda \mathrm{Ex} \max 484 \mathrm{~nm}, \lambda \mathrm{Ex}$ $\max 501 \mathrm{~nm}$ ) (Molecular Probes, Inc., Eugene, OR, USA) used at $40 \mathrm{nM}$ final concentration in U937 cells cultured for 18,24 , and $30 \mathrm{~h}$ in the absence or in the presence of $7 \alpha$-hydroxycholesterol $(80 \mu \mathrm{g} / \mathrm{ml})$, $7 \beta$-hydroxycholesterol $(20 \mu \mathrm{g} / \mathrm{ml})$, or 7 -ketocholesterol $(40 \mu \mathrm{g} / \mathrm{ml})$. This cyanine dye, which accumulates in the mitochondrial matrix under the influence of the $\Delta \psi_{\mathrm{m}},{ }^{101}$ was initially prepared at $1 \mathrm{mM}$ in DMSO (Sigma), and further diluted in distilled water in order to obtain a $20 \mu \mathrm{M}$ intermediate solution. To obtain a $40 \mathrm{nM}$ final concentration, $2 \mu \mathrm{l}$ of this intermediate solution were added to cell suspensions adjusted to $2 \times 10^{6} \mathrm{cells} / \mathrm{ml}$, and after $15 \mathrm{~min}$ of incubation at $37^{\circ} \mathrm{C}$, $\mathrm{DiOC}_{6}(3)$ mitochondrial transmembrane potential related fluorescence was immediately recorded by flow cytometry with a FACscan flow cytometer (Becton Dickinson). The green fluorescence was collected through a 524/44 $\mathrm{nm}$ band pass filter, and the fluorescent signals were 
measured on a logarithmic scale of four decades of log. For each sample, 10000 cells were acquired and the data were analyzed with the LYSYS I software (Becton Dickinson).

\section{Protein extraction and Western blot analysis}

Degradation of caspase- 9 and-3, cytochrome $c$ release into the cytosol, and cleavage of the poly(ADP-ribose) polymerase (PARP) were investigated by Western blot analysis of U937 cells incubated for 18,24 and $30 \mathrm{~h}$ in their culture medium in the absence or presence of $7 \alpha$-hydroxycholesterol ( $80 \mu \mathrm{g} / \mathrm{ml}), 7 \beta$-hydroxycholesterol $(20 \mu \mathrm{g} / \mathrm{ml})$ or 7 -ketocholesterol $(40 \mu \mathrm{g} / \mathrm{ml})$. Analyses of the degradation of caspase 9 and -3 were performed in Ripa buffer $(150 \mathrm{mM} \mathrm{NaCl}, 50 \mathrm{mM}$ Tris HC $\mathrm{pH} 8,0,0.1 \%$ SDS, $0.5 \% \mathrm{Na}$ desoxycholate) extracts. To this end, cells were harvested at the end of the treatment and washed one time with cold PBS. Cells were further resuspended in the lysis buffer consisting of Ripa buffer containing a mixture of protease inhibitors $(0.1 \mathrm{mM}$ phenylmethylsulfonylfluoride, $2.5 \mu \mathrm{g} / \mathrm{l}$ aprotinin, $10 \mu \mathrm{g} / \mathrm{ml}$ pepstatine A, $2.5 \mu \mathrm{g} / \mathrm{ml}$ trypsin inhibitors, and $5 \mu \mathrm{g} / \mathrm{ml}$ leupeptin). After $30 \mathrm{~min}$ of incubation at $4^{\circ} \mathrm{C}$ in the lysis buffer, cell debris was eliminated by centrifugation for $15 \mathrm{~min}$ at $10000 \times \mathrm{g}$ and the supernatant was collected.

For analysis of cytochrome $c$ release into the cytosol, cells were resuspended in buffer $A$ (20 mM HEPES-KOH pH 7.5, $10 \mathrm{mM} \mathrm{KCl}$, $1.5 \mathrm{mM} \mathrm{MgCl}_{2}, 1 \mathrm{mM}$ EDTA-Na, $1 \mathrm{mM}$ EGTA-Na, $1 \mathrm{mM}$ dithiothreitol) containing $250 \mathrm{mM}$ sucrose and a mixture of protease inhibitors $(1 \mathrm{mM}$ phenylmethylsulfonylfluoride, $1 \%$ aprotinin, $1 \mathrm{mM}$ leupeptin, $1 \mu \mathrm{g} / \mathrm{ml}$ pepstatin $\mathrm{A}$, and $1 \mu \mathrm{g} / \mathrm{ml}$ chymostatin). The cells were homogenized by successive passages through a $25 \mathrm{G}$ fine needle. Unbroken cells, large plasma membrane pieces, and nuclei were removed by centrifuging the homogenates for $10 \mathrm{~min}$ at $1000 \times \mathrm{g}$ and at $4^{\circ} \mathrm{C}$. The resulting supernatant was subjected to $10000 \times g$ at $4^{\circ} \mathrm{C}$ for $20 \mathrm{~min}$, and the supernatant obtained was centrifuged again for $1 \mathrm{~h}$ at $100000 \times g$ and at $4^{\circ} \mathrm{C}$ to generate cytosol.

For analysis of PARP, total cellular extracts were needed. The cell pellets were resuspended and incubated for $30 \mathrm{~min}$ at $4{ }^{\circ} \mathrm{C}$ in Laemnli's lysis buffer ( $1 \%$ SDS, $1 \mathrm{mM}$ sodium-vanadate, $10 \mathrm{mM}$ Tris-HCl) in the presence of protease inhibitors (1 $\mathrm{mM}$ phenylmethylsulfonylfluoride, $1 \%$ aprotinin, $1 \mathrm{mM}$ leupeptin, $1 \mu \mathrm{g} / \mathrm{ml}$ pepstatin $\mathrm{A}$, and $1 \mu \mathrm{g} / \mathrm{ml}$ chymostatin), and the cells were homogenized by successive passages through a $25 \mathrm{G}$ fine needle.

The protein concentrations were measured by using bicinchoninic acid reagent (Pierce, Rockford, IL, USA) according to the method of Smith et al. ${ }^{102}$ Thirty to $50 \mu \mathrm{g}$ of protein were incubated in loading buffer (125 mM Tris-HCl, pH 6.8, 10\% $\beta$-mercaptoethanol, 4.6\% SDS, $20 \%$ glycerol, $5 \mathrm{M}$ urea and $0.003 \%$ bromophenol blue), boiled for $3 \mathrm{~min}$, separated by SDS-polyacrylamide gel electrophoresis and electroblotted onto polyvinylidine difluoride membrane (Biorad, Ivry sur Seine, France). After blocking nonspecific binding sites overnight by $5 \%$ nonfat milk in TPBS (PBS, Tween $200.1 \%$ ), the membranes were incubated for $2 \mathrm{~h}$ at room temperature with various primary antibodies: a mouse monoclonal antibody directed against procaspase- 9 used at $2 \mu \mathrm{g} / \mathrm{ml}$ (Pharmingen), a rabbit polyclonal antibody directed against caspase-3 used at $2 \mu \mathrm{g} / \mathrm{ml}$ (Pharmingen, San Diego, CA, USA), a mouse monoclonal antibody directed against cytochrome $c$ also used at $2 \mu \mathrm{g} / \mathrm{ml}$ (Pharmingen), and a mouse monoclonal antibody directed against the PARP diluted 1/2000 (Boerhinger); all antibodies were diluted in TPBS. After two washes in TPBS, the membranes were incubated with horseradish peroxidase-conjugated goat anti-mouse (Dako, Coppenhagen, Denmark), or anti-rabbit antibody (Biorad) for $1 \mathrm{~h}$ at room temperature and washed twice in TPBS. Autoradiography of the immunoblots was performed using an enhanced chemoluminescence detection kit (Amersham, Les Ulis,
France). Autoradiograms were digitized using an image analysis system (Biocom). Quantitative analysis of cytochrome $c$ release was performed using autoradiography with a Biocom image analysis system and normalized against a cross reacting protein of around $65 \mathrm{kD}$ present in the cytosolic extract; ${ }^{62}$ in these conditions, cytochrome $c$ release was estimated with the Visiolab software (Biocom) by the ratio [cytochrome $c] /[65 \mathrm{kD}$ protein]. Each experiment was repeated three times with identical results.

\section{Fluorogenic assay for caspase-3 protease activity}

To assess caspase-3 activity, the cleavage of Ac-DEVD-7-amino-4methylcoumarin (Ac-DEVD-AMC) was measured according to the manufacturer procedure with the Quanti Pak ${ }^{\mathrm{TM}}$ kit (BIOMOL Research Laboratories, Plymouth Meeting, PA, USA) in U937 cells incubated for 18,24 and $30 \mathrm{~h}$ in their culture medium in the absence or presence of $7 \alpha$-hydroxycholesterol $(80 \mu \mathrm{g} / \mathrm{ml}), 7 \beta$-hydroxycholesterol $(20 \mu \mathrm{g} / \mathrm{ml})$ or 7-ketocholesterol $(40 \mu \mathrm{g} / \mathrm{ml})$, with or without ZVAD-fmk $(100 \mu \mathrm{M})$. Briefly, at the end of the incubation time, cells were counted, harvested by centrifugation $\left(1000 \times \mathrm{g}, 4^{\circ} \mathrm{C}, 10 \mathrm{~min}\right)$, and resuspended to $5 \times 10^{7}$ cells per $\mathrm{ml}$ of ice-cold lysis buffer $(50 \mathrm{mM}(\mathrm{N}-[(2-$ hydroxyethyl] piperazine-N'-[2-ethanesulfonic acid]) (HEPES), pH 7.4, 0.1\% (3[(3chloramidopropyl) dimethylammonio]-1-propane-sulfonate) (CHAPS), $1 \mathrm{mM}$ dithiothreitol (DTT), $0.1 \mathrm{mM}$ ethylenediaminetetraacetic acid (EDTA), $1 \%$ triton X-100). After 10 min of incubation in an ice bath, cells were centrifuged $\left(10000 \times \mathrm{g}, 4^{\circ} \mathrm{C}, 10 \mathrm{~min}\right)$, and the supernatant (cytosolic extract) was collected. For each assay, the cytosolic extract $(10 \mu \mathrm{l})$ was mixed with $80 \mu \mathrm{l}$ of assay buffer (50 mM HEPES, pH 7.4, $100 \mathrm{mM} \mathrm{NaCl}, 0.1 \%$ CHAPS, $10 \mathrm{mM}$ DTT, 1 mM EDTA, 10\% glycerol), and with $10 \mu \mathrm{l}$ of substrate solution (2 mM Ac-DEVD-AMC). The fluorescence of the liberated AMC was measured at room temperature at 2 min intervals for 40 min using a Victor ${ }^{2}$ microspectrofluorometer

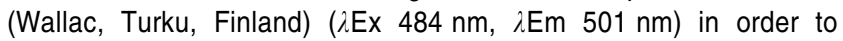
determine the specific activity of the assay. In these conditions, three independent experiments were performed in triplicate.

\section{Statistical analysis}

Statistical analyses were performed with SYSTAT software (Evanston, III.) using a one way and a two way analysis of variance.

\section{Acknowledgements}

This work was supported by the Conseil Régional de Bourgogne, the Institut National de la Santé et de la Recherche Médicale (Inserm), the Fondation pour la Recherche Médicale (FRM), and the Fondation de France. We thank Dr Serge Gueldry (Inserm U 498) for his expert statistical analysis, as well as Ms Maryvonne Moisant and Colette Bernard (Laboratoire de Microscopie Préparative Appliquée à la Biologie et à la Médecine) for their technical supports in electron microscopy. We also acknowledge the Centre de Microscopie Appliquée à la Biologie (Université de Bourgogne, Dijon, France) for the observations by transmission electron microscopy. The authors are also indebted to $\mathrm{Mr}$ John Ewing for reviewing the English version of this manuscript.

\section{References}

1. Smith $L$ (1996) Review of progress in sterol oxidations: 1987-1995. Lipids 31: $453-457$

2. Parish EJ, Nanduri VBB, Kohl HH and Taylor FR (1986) Oxysterols: chemical synthesis, biosynthesis and biological activities. Lipids 21: $27-30$ 
3. Smith LL (1987) Cholesterol autoxidation. Chem. Phys. Lipids 44: 87-125

4. Maraschiello C, Esteve E and Garcia Regueiro JA (1998) Cholesterol oxidation in meat from chicken fed alpha-tocopherol- and beta-carotene-supplemented diets with different insaturation grades. Lipids 33: 705-713

5. Przygonski K, Jelen $\mathrm{H}$ and Wasowicz E (2000) Determination of cholesterol oxidation products in milk powder and infant formulas by gas chromatography and mass spectrometry. Nahrung 44: $122-125$

6. Guardiola F, Codony R, Addis PB, Rafecas M and Boatella J (1996) Biological effects of oxysterols: current status. Food Chem. Toxicol. 34: 193-211

7. Morel DW and Lin CY (1996) Cellular biochemistry of oxysterols derived from the diet or oxidation in vivo. Nutr. Biochem. 7: 495-506

8. Bakos JT, Johnson BH and Thompson EB (1993) Oxysterol-induced cell death in human leukemic T-cells correlates with oxysterol binding protein occupancy and is independent of glucocorticoid-induced apoptosis. J. Steroid. Biochem. Mol. Biol. 46: 415-426

9. Lizard G, Lemaire S, Monier S, Gueldry S, Néel D and Gambert P (1997) Induction of apoptosis and of interleukin- $1 \beta$ secretion by $7 \beta$-hydroxycholesterol and 7-ketocholesterol: partial inhibition by Bcl-2 overexpression. FEBS Lett. 419: $276-280$

10. Peng SK, Tham P, Taylor CB and Mikkelson B (1979) Cytotoxicity of oxidation derivatives of cholesterol on cultured aortic smooth muscle cells and their effect on cholesterol biosynthesis. Am. J. Clin. Nutr. 32: 1033-1042

11. Lizard G, Deckert V, Dubrez L, Moisant M, Gambert P and Lagrost L (1996) Induction of apoptosis in endothelial cells treated with cholesterol oxides. Am. J. Pathol. 148: 1625-1638

12. Lizard G, Monier S, Cordelet $C$, Gesquière L, Deckert V, Gueldry S, Lagrost L and Gambert P (1999) Characterization and comparison of the mode of cell death, apoptosis versus necrosis, induced by $7 \beta$-hydroxycholesterol and 7 ketocholesterol in the cells of the vascular wall. Arterioscl. Thromb. Vasc. Biol. 19: $1190-1200$

13. Nishio $E$ and Watanabe $Y$ (1996) Oxysterols induced apoptosis in cultured smooth muscle cells through CPP32 protease activation and bcl-2 downregulation. Biochem. Biophys. Res. Comm. 226: 928-934

14. Aupeix K, Weltin D, Meija JE, Christ M, Marchal J, Freyssinet JM and Bischoff $P$ (1995) Oxysterol-induced apoptosis in human monocytic cell lines. Immunobiology 194: 415-428

15. Lizard G, Gueldry S, Sordet O, Monier S, Athias A, Miguet C, Besséde G, Lemaire S, Solary E and Gambert P (1998) Glutathione is implied in the control of 7-ketocholesterol-induced apoptosis, which is associated with radical oxygen species production. FASEB J. 12: 1651-1663

16. Lemaire S, Lizard G, Monier S, Miguet C, Gueldry S, Volot F, Gambert P and Néel D (1998) Different patterns of IL-1 $\beta$ secretion, adhesion molecule expression and apoptosis induction in human endothelial cells treated with $7 \alpha-$, $7 \beta$-hydroxycholesterol, or 7-ketocholesterol. FEBS Lett. 440: 434-439

17. Brown AJ and Jessup W (1999) Oxysterols and atherosclerosis. Atherosclerosis 142: 1-28

18. Berliner JA and Heinecke JW (1996) The role of oxidized lipoproteins in atherogenesis. Free Radical Biol. Med. 20: 707-727

19. Harada-Shiba M, Kinoshita M, Kamido Hand Shimokado K (1998) Oxidized low density lipoprotein induces apoptosis in cultured human umbilical vein endothelial cells by common unique mechanisms. J. Biol. Chem. 273: 9681 9687

20. Addis PB (1986) Occurrence of lipid oxidation products in foods. Food Chem. Toxicol. 24: 1021-1030

21. Kitanaka $C$ and Kuchino $Y$ (1999) Caspase-independent programmed cell death with necrotic morphology. Cell Death Differ. 6: 508-515

22. Vaux DL (1999) Caspases and apoptosis-biology and terminology. Cell Death Differ. 6: 493-494

23. Lizard G, Fournel S, Genestier L, Dhedin N, Chaput C, Flacher M, Mutin M, Panaye M and Revillard JP (1995) Kinetics of plasma membrane and mitochondrial alterations in cells undergoing apoptosis. Cytometry 21: 275283

24. Park SW and Addis PB (1985) Capillary column gas-liquid chromatographic resolution of oxidized cholesterol derivatives. Anal. Biochem. 149: 275-283

25. Petit PX, Lecoeur H, Zorn E, Dauget C, Mignotte B and Gougeon ML (1995) Alterations in mitochondrial structure and function are early events of dexamethasone-induced thymocyte apoptosis. J. Cell. Biol. 130: 157-167

26. Dubrez L, Savoy I, Hamman A and Solary E (1996) Pivotal role of DEVDsensitive step in eteoposide-induced and Fas-mediated apoptotic pathways. EMBO J. 15: 5504-5512
27. Hannun YA and Obeid LM (1995) Ceramide: an intracellular signal for apoptosis. Trends Biol. Sci. 20: 73-77

28. Jaffrezou JP, Levade T, Bettaieb A, Andrieu N, Bezombes C, Maestre N, Vermeersch S, Rousse A and Laurent G (1996) Daunorubicin-induced apoptosis: triggering of ceramide generation through sphingomyelin hydrolysis. EMBO J. 15: 2417-2424

29. Bettaieb A, Record M, Come MG, Bras AC, Chap H, Laurent G and Jaffrezou JP (1996) Opposite effects of tumor necrosis factor alpha on the sphingomyelinceramide pathway in two myeloid leukemia cell lines: role of transverse sphingomyelin distribution in the plasma membrane. Blood 15: 1465-1472

30. Rodriguez I, Matsuura K, Ody C, Nagata S and Vassalli P (1996) Systemic injection of a tripeptide inhibits the intracellular activation of CPP32-like proteases in vivo and fully protects mice against Fas-mediated fulminant liver destruction and death. J. Exp. Med. 184: 2067-2072

31. Wang E, Norred WP, Bacon CW, Riley RT and Merril AH (1991) Inhibition of sphingolipid biosynthesis by fumonisins. Implications for diseases associated with Fusarium noniliforme. J. Biol. Chem. 5: 14486-14490

32. Yeh CG, Hsi B and Faulk WP (1981) Propidium iodide as a nuclear marker in immunofluorescence. II. Use with cellular identification and viability studies. J. Immunol. Methods 43: 269-275

33. Green D and Kroemer G (1998) The central executioners of apoptosis: caspases or mitochondria? Trends Cell Biol. 8: 267-271

34. Sun XM, MacFarlane M, Zhuang J, Wolf BB, Green DR and Cohen GM (1999) Distinct caspase cascade are initiated in receptor-mediated and chemicalinduced apoptosis. J. Biol. Chem. 274: 5053-5060

35. Susin AS, Zamzami N and Kroemer G (1998) Mitochondria as regulators of apoptosis: doubt no more. Biochim. Biophys. Acta 1366: 151-165

36. Li P, Nijhawan D, Budihardjol, Srinivasula SM, Ahmad M, AlnemriES and Wang X (1997) Cytochrome $c$ and dATP-dependent formation of Apaf-1/caspase-9 complex initiates an apoptotic protease cascade. Cell 91: 479-489

37. De Murcia G and Menissier De Murcia J (1994) Poly(ADP-ribose)polymerase:a molecular nick-sensor. Trends Biochem. Sci. 19: 172-176

38. Perry DK and Hannun YA (1998) The role of ceramide in cell signaling. Biochim. Biophys. Acta 1436: 233-243

39. Hannun YA (1996) Functions of ceramide in coordinating cellular responses to stress. Science 274: 1855-1859

40. Watts JD, Gu M, Patterson SD, Aebersold R and Polverino AJ (1999) On the complexities of ceramide changes in cells undergoing apoptosis: lack of evidence for a second messenger funtion in apoptotic induction. Cell Death Differ. 6: 105-114

41. Jänicke RU, $\mathrm{Ng} P$, Sprengart ML and Porter AG (1998) Caspase-3 is required for cleavage of $\alpha$-fodrin but dispensable for cleavage of other death substrates in apoptosis. J. Biol. Chem 273: 15540-15545

42. Porter AG and Jänicke RU (1999) Emerging roles of caspases-3 in apoptosis. Cell Death Differ. 6: 99-104

43. Bose R, Verheil M, Haimovitz-Friedman A, Scotto K, Fuks Z and Kolesnick R (1995) Ceramide synthase mediates daunorubicin-induced apoptosis: an alternative mechanism for generating death signals. Cell 82: 405-414

44. Samali A, Zhivotovsky, Jones D, Nagata S and Orrenius S (1999) Apoptosis: cell death defined by caspase activation. Cell Death Differ. 6: 495-496

45. Lutjohann D, Papassotiropoulos A, Bjorkhem I, Locatelli S, Bagli M, Oehring RD, Schlegel U, Jessen F, Rao ML, Von Bergmann K and Heun R (2000) Plasma 24S-hydroxycholesterol (cerebrosterol) is increased in Alzheimer and vascular demented patients. J. Lipid Res. 41: 195-198

46. Best PJM, Hasdai D, Sangiorgi G, Schwartz RS, Holmes DR, Simari RD and Leman A (1998) Apoptosis. Basic concepts and implications in coronary artery disease. Arterioscler. Thromb. Vasc. Biol. 19: 14-22

47. Schroepfer GJ (2000) Oxysterols: modulators of cholesterol metabolism and other processes. Physiol. Rev. 80: 362-554

48. Bischoff PL, Holl V, Coelho D, Dufour P, Weltin D and Luu B (2000) Apoptosis at the interface of immunosuppressive and anticancer activities: the examples of two classes of chemical inducers, oxysterols and alkylating agents. Curr. Med. Chem. 7: 693-713

49. Chang JY, Chavis JA, Liu LZ and Drew PD (1998) Cholesterol oxides induce programmed cell death in microglial cells. Biochem. Biophys. Res. Commun. 249: 817-821

50. Chang JY and Liu LZ (1998) Neurotoxicity of cholesterol oxides on cultured cerebellar granule cells. Neurochem. Int. 32: 317-323 
51. Kolsch H, Lutjohann D, Tulke A, Bjorkhem I and Rao ML (1999) The neurotoxic effects of 24-hydroxycholesterol on SH-5Y human neuroblastoma cells. Brain Res. 818: 171-175

52. Gray MFT, Lawrie TDV and Brooks CJW (1971) Isolation and identification of cholesterol $\alpha$-oxide and other main sterols in human serum. Lipids 6: 836-843

53. Vine DF, Mamo JCL, Beilin LJ, Mori TA and Croft KD (1998) Dietary oxysterols are incorporated in plasma triglyceride-rich lipoproteins, increase their susceptibility to oxidation and increase aortic cholesterol concentration of rabbits. J. Lipid Res. 39: 1995-2004

54. Christ M, Luu B, Meija JE, Moosbrugger I and Bischoff P (1993) Apoptosis induced by oxysterols in murine lymphoma cells and in normal thymocytes. Immunology 78: 455-460

55. O'Callaghan YC, Woods JA and O'Brien NM (1999) Oxysterol-induced cell death in U937 and HepG2 cells at reduced and normal serum concentrations. Eur. J. Nutr. 38: 255-262

56. Luu B (1995) New insights on cholesterol and its oxidation compounds. C. R Soc. Biol. 189: 827-837

57. Hietter $H, B$ Bschoff $P, B e c k J P$, Ourisson G and Luu B (1986) Comprative effects of $7 \beta$-hydroxycholesterol towards murine lymphoma, lymphoblasts and lymphocytes: selective cytotoxicity and blastogenesis inhibition. Cancer Biochem. Biophys. 9: 75-83

58. Verhagen JC, ter Braake P, Teunissen J, van Ginkel G and Sevanian A (1996) Physical effects of biologically formed cholesterol oxidation products on lipid membranes investigated with fluorescence depolarization spectroscopy and electron spin resonance. J. Lipid Res. 37: 1488-1502

59. Bonnefoy-Bérard N, Genestier L, Flacher M, Rouault JP, Lizard G, Mutin M and Revillard JP (1994) Apoptosis induced by polyclonal antilymphocyte globulins in human B-cell lines. Blood 83: 1051 - 1059

60. Mehmet $\mathrm{H}$ (2000) Caspases find new place to hide. Nature 403: 29-30

61. Nakagawa T, Zhu H, Morishima N, Li E, Xu J, Yanker BA and Yuan J (2000) Caspase-12 mediates endoplasmic-reticulum-specific apoptosis and cytotoxicity by amyloid- $\beta$. Nature $403: 98-103$

62. Lizard G, Miguet C, Besséde G, Monier S, Gueldry S, Néel D and Gambert P (2000) Impairment with various antioxidants of the loss of mitochondrial transmembrane potential and of the cytosolic release of cytochrome c occuring during 7ketocholesterol-induced apoptosis. Free Radical. Biol. Med. 28: 743-753

63. Fiers W, Rudi B, Declercq W and Vandenabeele P (1999) More than one way to die: apoptosis, necrosis and reactive oxygen damage. Oncogene 18: 77197730

64. Slee EA, Adrain C and Martin SJ (1999) Serial killers: ordering caspase activation events in apoptosis. Cell Death Differ. 6: 1067-1074

65. Cai J, Yang J and Jones DP (1998) Mitochondrial control of apoptosis: the role of cytochrome c. Biochim. Biophys. Acta 1366: 139-149

66. LiP, Nijhawan D, Budihardjo I, Srinivasula SM, Ahmad M, Alnemri ES and Wang X (1997) Cytochrome $c$ and dATP-dependent formation of Apaf-1/caspase-9 complex initiates an apoptotic protease cascade. Cell 91: 479-489

67. Arora AS, Jones BJ, Patel TC, Bronk SF and Gores GJ (1997) Ceramides induces hepatocyte cell death through disruption of mitochondrial function in the rat. Hepatology 25: 958-963

68. Ghafourifar P, Klein SD, Schucht O, SchenkU, Pruschy M, Rocha Sand Richter $C$ (1999) Ceramide induces cytochrome $c$ release from isolated mitochondria. J. Biol. Chem. 274: 6080-6084

69. Cuvillier O, Edsall L and Spiegel S (2000) Involvement of spingosine in mitochondria-dependent Fas-induced apoptosis of type II Jurkat T cells. J. Biol. Chem. 275: $15691-15700$

70. Witty JP, Brigham JT and Johnson AL (1996) Induction of apoptotic cell death in hen granulosa cells by ceramides. Endocrinology 137: 5269-5277

71. Suzuki A, Iwasaki M, Kato M and Wagai N (1997) Sequential operation of ceramide synthesis and ICE cascade in CPT-11-initiated apoptotic death signaling. Exp. Cell Res. 233: 41-47

72. Garzotto M, White-Jones M, Jiang Y, Ehleiter D, Liao WC, Haimovitz-Friedman A, Fuks Z and Kolesnick (1998) 12-O -tetradecanoylphorbol-13-acetate induced apoptosis in LNCaP cells is mediated through ceramide synthase. Cancer Res. 58: 2260-2264

73. Escargueil-Blanc I, Andrieu-Abadie N, Caspar-Bauguil S, Brossmer R, Levade T, Nègre-Salvayre A and Salvayre R (1998) Apoptosis and activation of the sphingomyelin-ceramide pathway induced by oxidized low density lipoproteins are not causally related in ECV-304 endothelial cells. J. Biol. Chem. 273: $27389-27395$
74. Sevanian A, Hodis HN, Hwang J, McLeod LL and Peterson H (1995) Characterization of endothelial cell injury by cholesterol oxidation products found in oxidized LDL. J. Lipid Res. 36: 1971-1986

75. Cornell R, Grove GL, Rothblat GH and Horwitz AF (1977) Lipid requirement for cell cycling. The effect of selective inhibition of lipid synthesis. Exp. Cell Res. 109: 299-307

76. Hyun JW, Weltin D, Holl V, Marchal J, Dufour P, Luu B and Bischoff $P$ (1997) Cytotoxic properties of phosphoglycoconjugated derivative of $7 \beta$-hydroxycholesterol upon normal and tumorcells in culture. Anticancer Res. 17:2621-2626

77. Nickels JT and Broach JR (1996) Ceramide-activated protein phosphatase mediates ceramide-induced G1 arrest of Sacharomyces cerevisae. Genes Dev. 10: 382-394

78. Jayadev S, Liu B, Bielawska AE, Lee JY, Nazaire F, Pushkareva MY, Obeid LM and Hannun YA (1995) Role in ceramide in cell cycle arrest. J. Biol. Chem. 270: 2047-2052

79. Lazier CB and Bapat BV (1988) Antiestrogen binding sites : general and comparative properties. J. Steroid Biochem. 31: 665-669

80. Lin $L$ and Hwang PL (1991) Antiproliferative effects of oxygenated sterols: positive correlation with binding affinities for the antiestrogen-binding sites. Biochim. Biophys. Acta 1082: 177-184

81. Kandutsch AA, Taylor FR and Shown EP(1984) Differentforms of the oxysterolbinding protein. Binding kinetics and stability. J. Biol. Chem. 259: 1238812397

82. Levanon D, Hsieh CL, Francke U, Dawson PA, Ridgway ND, Brown MS and Goldstein JL (1990) CDNA cloning of human oxysterol-binding protein and localization of the gene to human chromosome 11 and mouse chromosome 19. Genomics 7: 65-74

83. BesemeF, Astruc ME, Defay Rand Crastes de Paulet A(1987) Rat liver cytosolbinding protein. Characterization and comparison with the HTC cell protein. FEBS Lett. 210: 97-103

84. Kandutsch AA and Chen HW (1974) Inhibition of sterol synthesis in cultured mouse cells by cholesterol derivatives oxygenated in the side chain. J. Biol. Chem. 249: 6057-6061

85. Farnier $M$ and Davignon $J(1998)$ Current and future treatment of hyperlipidemia: the role of statins. Am. J. Cardiol. $82: 3 \mathrm{~J}-10 \mathrm{~J}$

86. Bansal N, Houle AG and Melnykovych G (1989) Comparison of dexamethasone and lovastatin (mevinolin) as growth inhibitors in cultures of T-cell derived from human acute leukemia lines (CEM). Leuk. Res. 13: 875-882

87. Guijarro C, Blanco-Colio LM, Ortego M, Alonso C, Ortiz A, Plaza JJ, Diaz C, Hernandez $G$ and Egido J (1998) 3-hydroxy-3-methylglutaryl coenzyme A reductase and isoprenylation inhibitors induce apoptosis of vascular smooth muscle cells in culture. Circ. Res. 83: 490-500

88. Edwards PA and Ericsson J (1999) Sterols and isoprenoids: signaling molecules derived from the cholesterol biosynthetic pathway. Annu. Rev. Biochem. 68: 157-185

89. Gadbut AP, Wu L, Tang D, Papageorge A, Watson JA and Galper JB (1997) Induction of the cholesterol metabolic pathway regulates the farnesylation of RAS in embryonic chick heart cells: a new role for RAS in regulating the expression of muscarinic receptors and G proteins. EMBO J 16: 7250 - 7260

90. Kennedy SG, Wagner AJ, Conzen SD, Jordan J, Bellacosa A, Tsichilis PN and Hay N (1997) The PI3-kinase / Akt signaling pathway delivers an anti-apoptotic signal. Gene Dev. 11: 701-713

91. Kauffmann-Zeh A, Rodriguez-Viciana P, Ulrich E, Gilbert C, Coffer P, Downward J and Evan G (1997) Suppression of C-Myc-induced apoptosis by Ras signalling through PI(3)K and PKB. Nature 386: 544-548

92. Zha J, Harada H, Yang E, Jockel J and Korsmeyer SJ (1996) Serine phosphorylation of death agonist Bad in response to survival factor results in binding to 14-3-3 not Bcl-XL. Cell 87: 619-628

93. Datta SR, Dudek H, Tao X, Masters S, Fu H, Gotoh Y and Greenberg ME (1997) Akt phosphorylation of BAD couples survival signals to the cell-intinsic death machinery. Cell 91: 231-241

94. Kennedy SG, Kandel ES, Cross TK and Hay N (1999) Akt/protein kinase B inhibits cell death by preventing the release of cytochrome $c$ from mitochondria. Mol. Cell. Biol. 19: 5800-5810

95. Lehmann JM, Kliewer SA, Moore LB, Smith-Oliver TA, Oliver BB, Su JL, Sunseth SS, Winegard DA, Blanchard DE, Spencer TA and Wilson TM (1997) Activation of the nuclear receptor LXR by oxysterols defines a new hormone response pathway. J. Biol. Chem. 272: 3137-3140 
96. Peet DJ, Janowski BA and Mangeldorf DJ (1998) The LXRs: a new class of oxysterol receptors. Curr. Opin. Genet. Dev. 8: 571-575

97. Pai JT, Brown MS and Goldstein JL (1996) Purification and cDNA cloning of a second apoptosis-related cysteine protease that cleaves and activates sterol regulatory element binding proteins. Proc. Natl. Acad. Sci. USA 93: 5437-5442

98. Lund EG, Kerr TA, Sakai J, Li WP and Russell DW (1998) cDNA cloning of mouse and human cholesterol 25-hydroxylases, polytopic membrane proteins that synthetize a potent oxysterol regulator of lipid metabolism. J. Biol. Chem. 343: $16-27$

99. Folch J, Lees M and Sloane Stanley GH (1957) A simple method for the isolation and purification of total lipids from animal tissues. J. Biol. Chem. 226: 497-509
100. Gu M, Kervin JL, Watts JD and Aebersold R (1997) Ceramides profiling of complex lipid mixtures by electrospray ionization mass spectrometry. Anal. Biochem. 244: 347-356

101. Chen LB (1988) Mitochondrial membrane potential in living cells. Annu. Rev. Cell. Biol. 4: 155-181

102. Smith PK, Krohn RI, Hermanson GT, Mallia AK, Gartner FH, Provenzano MD, Fujimoto EK, Goeke NM, Olson BJ and Klenk DC (1985) Measurement of protein using bicinchoninic acid. Anal. Biochem. 150: 76-85 